\title{
Diagenesis and reservoir space types of alkaline lake-type shale in Fengcheng Formation of Mahu Sag, Junggar Basin, China
}

\author{
Yang Zhifeng ${ }^{1} \cdot$ Tang Yong $^{1} \cdot$ Guo Xuguang $^{1} \cdot$ Huang Liliang ${ }^{1} \cdot$ Chang Qiusheng $^{1}$
}

Received: 6 April 2021 / Accepted: 13 October 2021 / Published online: 8 November 2021

(c) The Author(s) 2021

\begin{abstract}
Using observations and descriptions of drilling cores, image logging, microscopic section, argon ion polishing field emission scanning electron microscopy, X-ray diffraction, and whole-rock trace element analysis, the study of shale reservoir diagenesis and space types in the Fengcheng Formation of the Mahu Sag was conducted. Considering the trace element contents and their ratios $(\mathrm{Sr} / \mathrm{Ba}, \mathrm{V} / \mathrm{Ni}, \mathrm{Th} / \mathrm{U}, \mathrm{V} /(\mathrm{V}+\mathrm{Ni}), \mathrm{U} / \mathrm{Mo}$, and $\mathrm{Sr} / \mathrm{Cu})$, the Fengcheng Formation is formed in a dry and hot continental lacustrine basin with a paleoenvironment of saltwater and anoxic/lean oxygen conditions. The shale reservoirs of the Fengcheng Formation with the characteristic of multisource mixed sedimentation include terrigenous clastic, volcaniclastics, and carbonate rocks. Currently, the Fengcheng reservoir of the Mahu Sag is in the middle of diagenetic-stage B. The principal factors for reservoir densification are compaction, dissolution, carbonate mineral cementation, and clay mineral cementation. The Fengcheng Formation develops multiple reservoir storage space types, such as rock fractures, stylolites, and micro-nanoscale pore-throat systems. The macroreservoir space types include tectonic, induced, bedding, and dissolution-expansion fracture types. The microreservoir space types include microfractures, stylolites, and micro-nanoscale pore throats. The research showed that the Fengcheng Formation has tectonic fracture-pore systems (tectonic fracture-type reservoirs) and stylolite-matrix pore-tectonic microfracture systems (shale oil reservoirs), forming the shale oil preponderant charging channel network. Reservoir space type and its spatial distribution are the principal factors for shale oil accumulation of the Fengcheng Formation in the Mahu Sag.
\end{abstract}

Keywords Diagenesis type $\cdot$ Reservoir space types $\cdot$ Shale reservoir $\cdot$ Fengcheng Formation $\cdot$ Junggar Basin

\section{Introduction}

Great successes in the Bakken shale area in the Williston Basin (Kuhn et al. 2012; Pollastro et al. 2012; Angster and Sarg 2013), the Eagle Ford shale area in the western Gulf of Mexico Basin (Hentz et al. 2014; French et al. 2019; Fairbanks et al. 2016), the Wolfcamp Formation in the Permian Basin (Ojha et al. 2018), the Niobara Formation in the Denver Basin (Han et al. 2019), and the Paleogene Green River shale area in the Green River Basin (Burton et al. 2014; Sarg et al. 2013; Burnham 2017) have changed the oil and gas supply pattern of North America, causing

Responsible Editor: Santanu Banerjee

Yang Zhifeng

303558056@qq.com

1 Xinjiang Oilfield Company Ltd., PetroChina, Karamay 834000, Xinjiang, China a worldwide upsurge in shale oil and gas exploration and exploitation. Compared with the geological characteristics of North American shale oil, with an open-sea deposition, single lithology, source-reservoir separation, and a concentrated distribution of sweet spots, Chinese shale oil has the characteristics of terrestrial multisource mixed sedimentation, source-reservoir transition, and scattered sweet spots. Affected by high-frequency climate change, continental shale reservoirs with characteristics of frequent facies change, a complex lithology, and strong heterogeneity have diverse sedimentary environments. Shale oil in China is mainly distributed in continental lacustrine basins as follows: Cretaceous of the Songliao Basin (Cao et al. 2017), Paleogene of the Bohai Bay Basin (eastern China) (Chao et al. 2017; Chen et al. 2017; Lu et al. 2015), Triassic of the Ordos Basin (Cui et al. 2019; Lai et al. 2016; Sun et al. 2020; Jiang et al. 2017; Yao et al. 2009; Wei et al. 2019), Jurassic of the Sichuan Basin (central China) (Li et al. 2018; Wang 
et al. 2018), and Permian of the Junggar Basin (western China) (Zhang et al. 2019a, b, c; Luo et al. 2018).

Shale oil originally only referred to oil related to oil shale. Later, as the exploration degree of unconventional oil and gas resources and related research improved, many institutions and scholars expanded the definition and connotation of shale oil and formed the following mainstream understanding. (1) Shale oil refers to petroleum resources rich in organic shale. Shale formation is a hydrocarbon source rock and a reservoir that is more compact than sandstone and carbonate tight oil reservoirs (Zou et al. 2019a, b). (2) The concept of shale oil is equivalent to tight oil, typically referring to petroleum resources stored in tight oil-bearing formations having low porosity and permeability (Clarkson and Pedemen 2011; Zhang et al. 2019a, b, c). (3) Shale oil refers to oil and gas resources in the shale oil and gas system, including organic-rich mudstone and shale as well as the interbedded and adjacent organic-poor reservoirs (Jarvie 2012; EIA 2013; Bowker 2007; Blaizot 2017). In this study, shale oil refers to petroleum resources accumulated in the hydrocarbon source-rock strata or shale system. Its reservoir thickness is less than $5 \mathrm{~m}$, layer thickness ratio is less than $50 \%$, and overburden matrix permeability is less than $0.1 \mathrm{mD}$ (Nelson et al. 2011). Horizontal drilling and multistage-fracturing technology must be used to realize economic exploitation. Shale pores are mainly nanopores (Zhang et al. 2019a, b, c). The pore throats of marine shale are distributed in the range of $0.005-0.05 \mu \mathrm{m}$. The radius of some pore throats is as high as $0.1 \mu \mathrm{m}$, including the radius of intergranular, intragranular, and organic pores (Yan et al. 2018; Guo et al. 2018; Fu et al. 2015). The main diageneses of shale reservoirs are compaction, cementation, dissolution, and metasomatism (Dowey and Taylor 2020; Taylor and Macquaker 2014; Milliken et al. 2012). Compaction is critical in the densification of shale reservoirs, and cementation has a certain destructive effect on reservoirs (Petrash et al. 2016).

The Fengcheng Formation of the Mahu Sag, Junggar Basin, is the oldest alkaline lake deposit discovered in China, containing rich unconventional oil and gas resources. Earlier studies have proposed that the Fengcheng Formation is the main source-rock series that is extensively distributed in the Mahu Sag. Deepening geological theory knowledge and progress in exploration and development technology has confirmed that the Fengcheng Formation of the Mahu Sag is a new field for shale oil exploration in a continental saline lacustrine basin with a rich resource potential. It is critical to understand the control factors of alkaline laketype shale in the Fengcheng Formation. Unfortunately, the control factors have rarely been studied. Current research on the Fengcheng Formation of the Mahu Sag mainly focuses on the sedimentary environment analysis of the source rock (Cao et al. 2015, 2020; Wang et al. 2020; Lu et al. 2015), organic geochemical characteristics (Tao et al. 2016; Yu et al. 2018), thermal evolution stage, genesis of dolomitic rocks (Zhu et al. 2016a, b), and hydrocarbon-generation potential (Zhang et al. 2018). However, diagenesis of various lithologies deposited in the saline lacustrine environment of the Fengcheng Formation and Mahu Sag has not been studied in detail. Furthermore, there is a lack of systematic research on the petrological characteristics, diageneticstage division, reservoir space types, and genetic mechanism analysis of shale reservoirs. In this study, the mineral composition, rock classification, nomenclature, sedimentary environment, diagenetic evolution sequence, and multiscale reservoir space types of the alkaline lake-type shale reservoir of the Fengcheng Formation in the Mahu Sag are studied. The combination model for reservoir space of shale oil is established.

\section{Geological setting}

The Mahu Sag is in the southeast of the western uplift of the Junggar Basin. Its paleogeomorphic features are asymmetrical pan-shaped sags with steep west and gentle east east-west zonations and north-south segments, including a central depression, volcanic highlands, structural slope breaks, and other geomorphological units. The Mahu Sag is adjacent to the Wuxia fault zone in the west, covering approximately $5000 \mathrm{~km}^{2}$. The Fengnan area is in the Mabei slope area of the Mahu Sag. The Mesozoic has three sets of oil-bearing combinations, namely, the Baikouquan Formation of the Triassic system, the Lower Wuerhe Formation of the Upper Permian series, and the Fengcheng Formation of the Lower Permian series. The Fengnan area is bounded by the Wuxia fault zone in the north, the Baiwu fault zone in the west, and the Mahu Sag in the southeast, covering approximately $600 \mathrm{~km}^{2}$ (Fig. 1). According to the difference in the structural characteristics, the Fengnan area can be divided into three subtectonic units from the west to the east, namely, the Wuxia thrust belt, the central fault-fold area, the slope belt, and the eastern uplift zone. The Fengcheng Formation of Lower Permian in the Junggar Basin is a semideep-deep lacustrine sedimentary environment with three types of reservoirs of terrigenous fan delta glutenite, volcanic rocks, and lacustrine fine-grained dolomite ( $\mathrm{Li}$ et al. 2021). During the sedimentation period of the Fengcheng Formation, the transgression period is from the late stage

Fig. 1 a Sketch map showing the location of the Mahu Sag, Junggar Basin. b The Mahu Sag is at the northwestern part of the Junggar Basin. c Sedimentary facies map of the study area. d Sedimentary facies profile of the Fengcheng Formation 

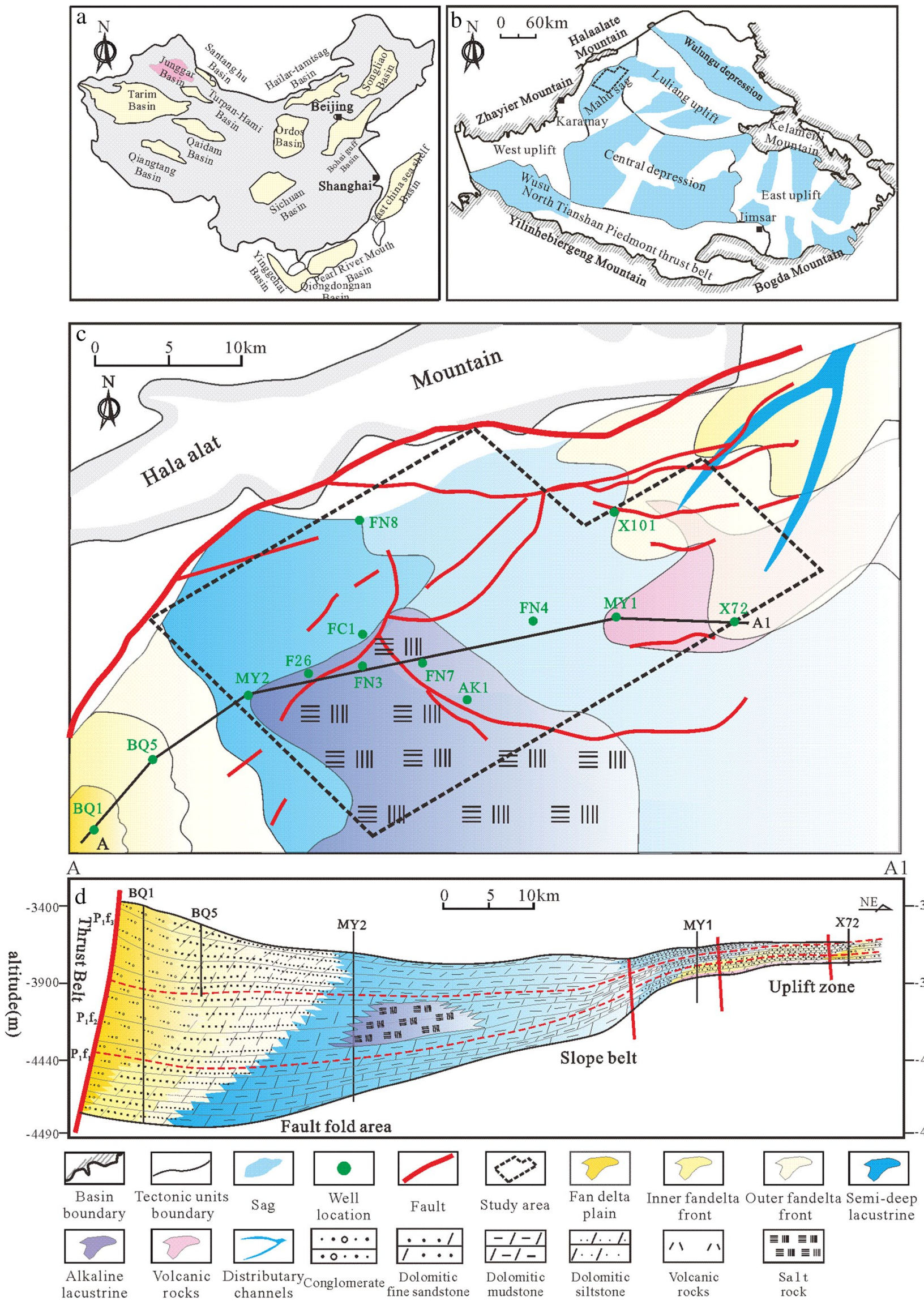
of the first member $\left(\mathrm{P}_{1} \mathrm{~F}_{1}\right)$ to the early stage of the second member $\left(\mathrm{P}_{1} \mathrm{~F}_{2}\right)$ and it then gradually regresses, forming the Fengcheng Formation's wide-covered high-quality source rock (Zhang et al. 2018).

Under this sedimentary background, the Fengcheng Formation has developed a lithological sequence from organicrich shales to tight volcanic rocks, forming two types of unconventional oil and gas reservoirs (Hu et al. 2015). (1) The third and second members of the Fengcheng Formation are typical shale reservoirs with integrated sources and reservoirs $\left(\mathrm{P}_{1} \mathrm{~F}_{3}\right.$ and $\left.\mathrm{P}_{1} \mathrm{~F}_{2}\right)$. (2) The first member of the Fengcheng Formation $\left(\mathrm{P}_{1} \mathrm{~F}_{1}\right)$ is a tight volcanic-rock reservoir of adjacent hydrocarbon source rocks. The dolomitic reservoirs of the third and second members contain abundant shale oil resources. Their lateral distribution is stable and widely developed, comprising four fine-grained sedimentary types, such as argillaceous dolomite, dolomitic mudstone, dolomitic siltstone, and dolomitic tuff. Vertically, lacustrine dolomitic reservoirs and dark-mud shale are interbedded and these reservoirs are tight and contain oil in a large area. The Fengcheng reservoirs' porosity in the western slope of the Mahu Sag is $1-13 \%$, with an average of $2.89 \%$, and its permeability is less than $0.1 \mathrm{mD}$, exhibiting overall characteristics of low porosity and compactness. The shale oil is characterized by low crude-oil density $\left(0.82-0.87 \mathrm{~g} / \mathrm{cm}^{3}\right)$, a low freezing point $\left(-14.8-5{ }^{\circ} \mathrm{C}\right)$, and high crude-oil viscosity $\left(2.75-770.4 \mathrm{mPa} \bullet \mathrm{s}\right.$ at $\left.50{ }^{\circ} \mathrm{C}\right)$. It is estimated that the current shale oil resources in the western slope zone of the Mahu Sag amount to 420 million tons, which is critical for the Junggar Basin to increase production and reserves in future.

\section{Method experiment}

From the main intervals of the $\mathrm{P}_{1} \mathrm{~F}_{2}$ and $\mathrm{P}_{1} \mathrm{~F}_{3}$ shale reservoirs, 100 core samples were collected from 21 wells. The core sample lithology includes terrestrial clastic rocks, carbonates, pyroclastic rocks, salt rocks, and mixed rocks. The samples were analyzed using techniques such as thin section (TS), X-ray fluorescence spectroscopy (XRF), X-ray diffraction (XRD), and field emission scanning electron microscopy (FE-SEM). In total, 220 TSs were analyzed. The TSs were impregnated with epoxy to microscopically observe sedimentary pore structures and diagenesis. Casting TSs were observed using petrographic microscopes to distinguish the pore genesis and types. The trace element, whole rocks, and clay mineral contents of the shale samples were identified at the China National Petroleum Corporation (CNPC) in Hangzhou. SEM and FE-SEM were conducted at the Xinjiang laboratory of petroleum resources in conglomerate, at the Xinjiang Oilfield Company, PetroChina.
Trace element analysis XRF analysis of trace elements in rock samples was performed using the compression molding method. The instrument was Panalytical Axios, and the implementation standard was Silicate Rock Chemical Analysis Method Part 28 to determine 16 major and minor components (GB/T 14,506.28, 2010). The temperature in the laboratory was $21{ }^{\circ} \mathrm{C}$ and humidity $23 \%$.

XRD The whole-rock and clay mineral contents of the core samples were detected using TTR XRD produced by the Rigaku Motor Company in Japan, following SY/T51632010. Whole-rock mineral analysis used 200 mesh powder samples, and each mineral's mass percentage was calculated using an analysis software and referred to the $\mathrm{K}$ value of international standard samples. The relative mineral percentage was measured semiquantitatively. The temperature in the laboratory was $24{ }^{\circ} \mathrm{C}$ with $35 \%$ humidity.

FE-SEM The FEI Quanta200F type SEM and Apreo S type FE-SEM were used for observation. Before the observation, the smoothed sample's surface was polished with argon ion and the rock sample was preprocessed following the SEM analysis standard (SY/T5162-2014) of the rock sample issued by the CNPC. Before sample processing, remove residual oil. The temperature in the laboratory was $25^{\circ} \mathrm{C}$ with $35 \%$ humidity.

\section{Results}

\section{Mineral composition content and rock classification nomenclature}

The Fengcheng Formation in the Mahu Sag is the oldest alkaline lacustrine deposition in China. It developed a suite of transitional mixed rocks (terrestrial clastic rocks, endogenous chemical sedimentary rocks, and volcaniclastics materials), and the mineral types in this formation are diverse (Fig. 2). Terrestrial clastic rocks are distributed in the fan delta sedimentary area at the edge of the lake basin, mainly composed of conglomerates, fine-grained sand, and siltstones. The mineral components are mainly feldspar and quartz, and the content of clay minerals is less (Fig. 3a, b). Quartz and feldspar grains are angular and subangular. Detrital particles in the sandstone are well sorted and highly rounded. The feldspar and rock debris contents are high, and the interstitial material is mainly argillaceous, with occasional calcareous cementation. Microbedding planes are developed in the mud shale and are mostly filled with organic matter in the later stage. Carbonates are widely distributed in the shallow-shore and semideep lacustrine sedimentary areas comprising endogenous calcite, dolomite, ankerite, ferrocalcite, and other minerals (Fig. 3c-f). 
Fig. 2 Mineralogical composition and clay mineral content of the Fengcheng Formation in the Mahu Sag, Junggar Basin

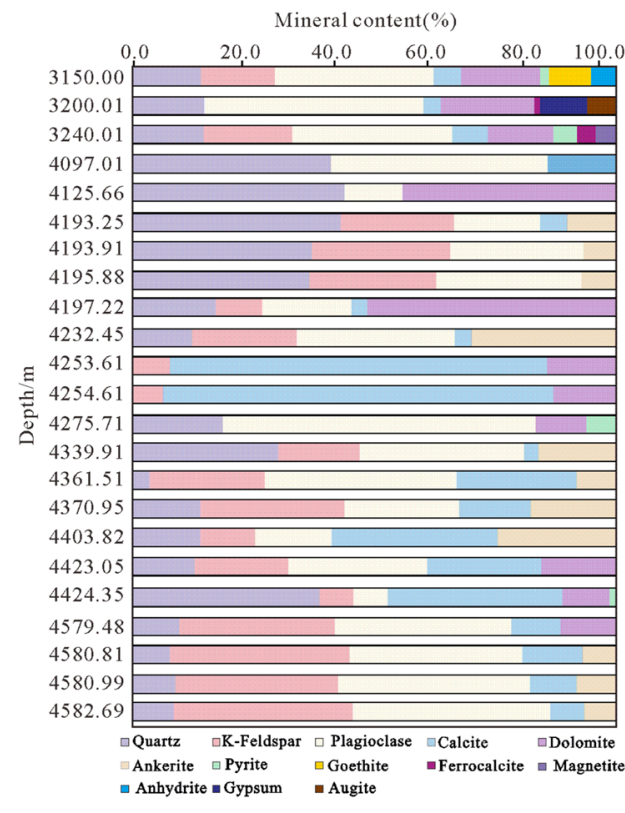

a Mineral content

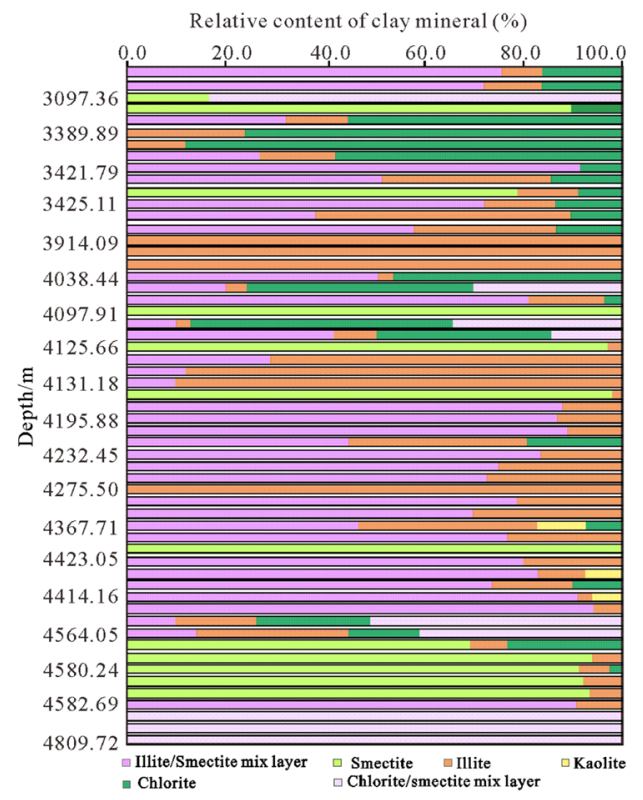

$\mathrm{b}$ The relative content of clay mineral
Significant differences exist in the grain size and crystal shape of dolomite minerals, including micrite, powder, and fine and medium crystals. The micritic and silt-crystalline dolomites are uniformly distributed in the rock, and the local occurrence is laminated. Fine- and intermediate-grained dolomites are enriched and distributed along fractures and microbedding planes.

Pyroclastic rocks have porous structures and are rich in volcanic materials such as crystal fragments and glass shards (Fig. $3 \mathrm{~g}, \mathrm{~h}$ ). The crystalline shape is angular and medium and has poor sorting, and the mineral composition is mainly quartz, feldspar with a small amount of biotite, local silicification, and chloritization phenomenon. Salt rocks mainly include alkaline minerals (sodium carbonate and bicarbonate), $\mathrm{Na}-\mathrm{Ca}-\mathrm{Mg}$-type carbonate (shortite and northupite), and reedmergnerite (Fig. 3i-n). Sodium carbonate is mostly of medium-coarse crystal structure, and the aggregate is mostly intersected plate columnar with low hardness. Trona minerals have crystal optical characteristics of a colorless, fibrous crystal shape; negative low protrusion; and a senior white interference color. Most mineral aggregates of shortite are plate like or short columns. They are for clarity or light yellow, have a negative low protrusion, and appear red after being dyed by potassium ferricyanide and alizarin red mixture. The reedmergnerite aggregates are gray or light gray, and the morphologies are dense banded or lenticular. Mixed rocks are distributed in the shoreline shallow lake sedimentary area, which is dominated by mixed accumulation, and the laminated structure is relatively developed. Sedimentary structures mainly include compact massive, horizontal bedding, interlaced bedding, and algae laminated (Fig. 3o-r).
The Fengcheng Formation, comprising complex and diverse mineral types, has a massive resource potential, with the appearance of high alkaline and accessory mineral contents. The existing classification and nomenclature standards make it challenging to reveal rock characteristics of the alkaline lacustrine shale formation. Many problems exist for the classification and nomenclature of organic-rich shale in China and abroad, including chaotic nomination, abusive, and scientifically illogical. Moreover, the classification and nomenclature of alkaline lacustrine shale formation have not been studied systematically (Lazar et al. 2015; Camp et al. 2016). Foreign experts have considered felsic, clay, and carbonate minerals as three endmembers for the classification of organic-rich shale (Gamero-Diaz et al. 2013; Xiong et al. 2019).

Based on the literature research and analysis as well as geological characteristics of the alkaline mineral composition and sedimentary structure in the core scale, this study proposes a new method for classifying rock types of alkaline lacustrine shale formations. Felsic, carbonate, pyroclastic, alkaline minerals, and sedimentary structures were used as the classification endmembers of alkaline lacustrine shale formations. A ternary diagram of terrestrial detrital, carbonate particles, and pyroclastic rocks was established. Two critical parameters-alkaline mineral component content and sedimentary structure in core scales-were introduced into a petrological triangle classification system of shale formations. Based on the 50\% content of main rock mineral components such as felsic, carbonate, tuff, and alkaline minerals, the basic name of the Fengcheng Formation was determined. The Fengcheng Formation reservoirs of alkaline 

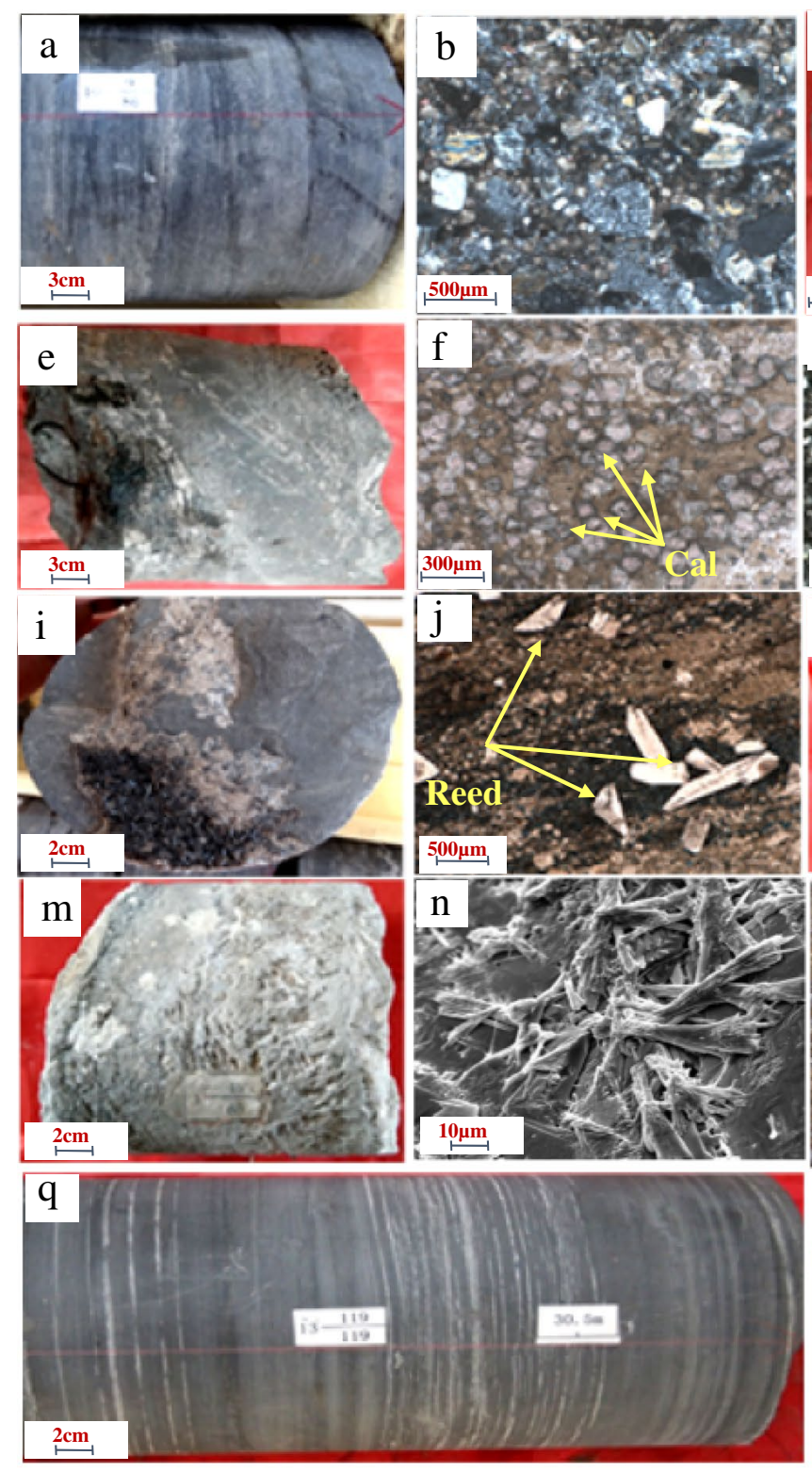

Fig. 3 Photographs showing the main rock types of the Fengcheng Formation in the Mahu Sag, Junggar Basin. a Argillaceous siltstone, terrigenous clastic rocks, from well MY1, $4813.81 \mathrm{~m}, \mathrm{CP}$. b Quartz and feldspar grain are well developed, argillaceous siltstone, from well MY1, $4813.81 \mathrm{~m}$, XPL. c Argillaceous dolomite, carbonates, from well F18, 3149.42 m, CP. d Late calcite replaced dolomicrite (the calcite was dyed red), argillaceous dolomite, from well F18, $3149.42 \mathrm{~m}$, PPL. e Argillaceous limestone, carbonates, from well FN3, 4128.79 m,CP. f Calcites grain are euthedral in shape, argillaceous limestone, carbonates, from well FN3, 4128.79 m, PPL. g crystal fragments and glass shards, tuff, pyroclastic rocks, from well MY1, $4595.59 \mathrm{~m}$, XPL. h crystal fragments, glass shards and dolomite cement are coexisting, dolomitic tuff, pyroclastic rocks, from well MY1, $4633.91 \mathrm{~m}$, PPL. i Mudshale containing reedmergnerite, from well MY1, 4719.59 m, CP. j Reedmergnerite grain are euthe-
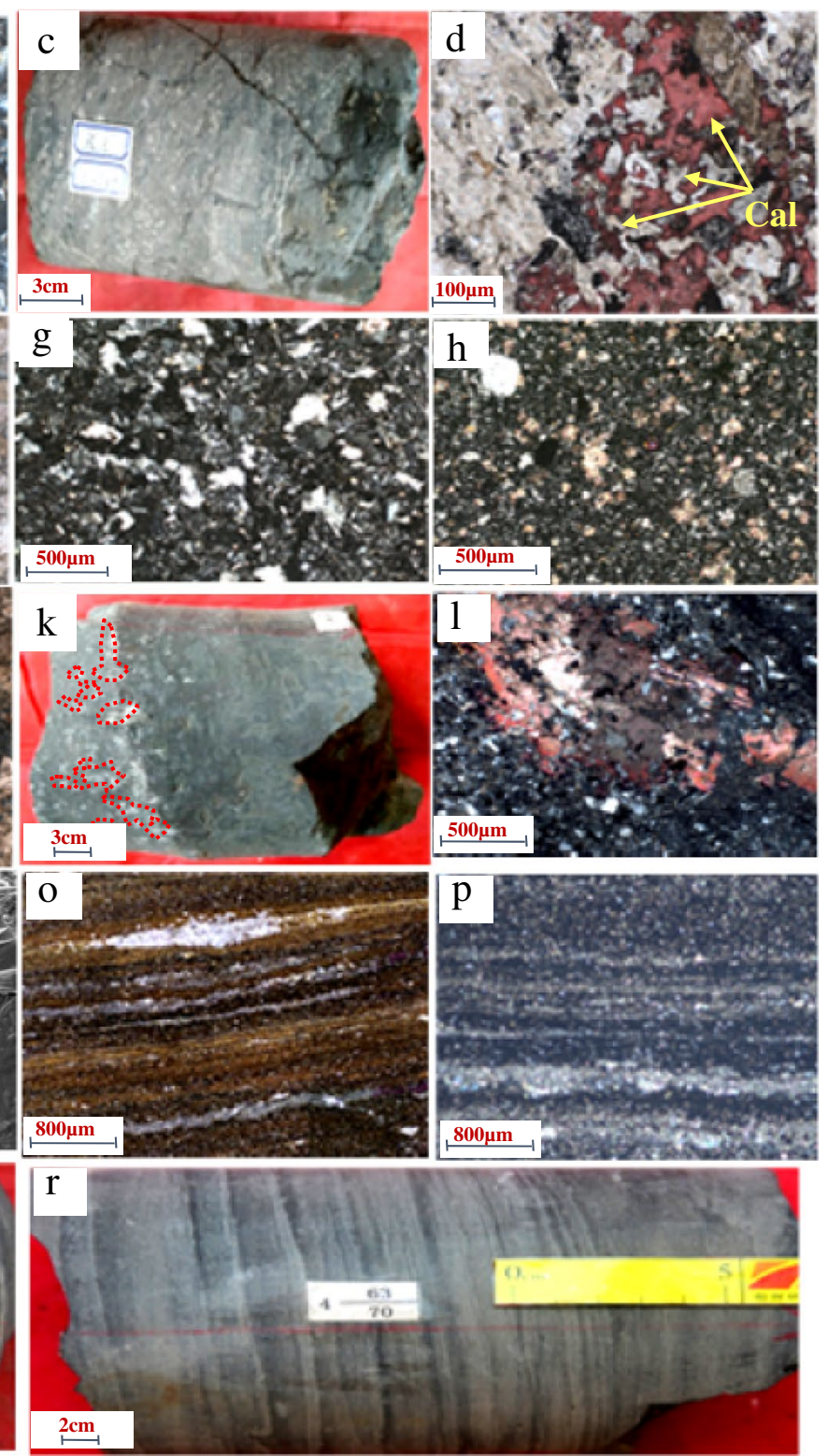

dral in shape, mudshale containing reedmergnerite, from well MY1, 4719.59 m, PPL. k Mudshale containing shortite, Na-Ca type carbonates, from well FN4, $4579.51 \mathrm{~m}, \mathrm{CP}$. 1 Shortite aggregate, mudstone containing shortite (dyed red), Na-Ca type carbonates, from well FN4, $4579.51 \mathrm{~m}$, XPL. m Alkaline mineral, from well FN5, 4069.72 m, CP. n Radial sodium carbonate aggregate, Na type carbonates, from well FN5, $4069.72 \mathrm{~m}$, SEM. o Aphanitic quartz and laminated texture is well developed, siliceous shale, from well MY1, 4789.56 m, PPL. p Fine-grained laminnae of silty mud, organic matter are well developed, from well MY1, 4790.32 m, XPL. q Grey black mudstone, from well MY1, $4774.31 \mathrm{~m}, \mathrm{CP}$. r Argillaceous siltstone, cross bedding structure, from well MY1, $4618.42 \mathrm{~m}, \mathrm{CP}$. (PPL plane-polarized light, XPL cross polarized light, CP core photos, SEM scanning electron microscope, Q quartz, Cal calcite, Reed Reedmergnerite) 
lakes were divided into (I) terrestrial clastic rocks, (II) carbonates, (III) pyroclastic rocks, and (V) salt rocks. If the mineral components of felsic, carbonates, tuff, and alkaline minerals were all less than $50 \%$, they were named mixed rocks (IV).

According to the mineral composition (25-50\%), rock names could be further subdivided. Terrestrial clastic rocks were subdivided into dolomitic/calcareous and tuffaceous sandstone. Carbonate rocks could be subdivided into tuffaceous dolomite/limestone and sandy dolomite/limestone. Pyroclastic rock could be subdivided into sandy and dolomitic/lime tuff. Salt rocks (V) of the Fengcheng Formation were composed of Na-type carbonates, $\mathrm{Na}-\mathrm{Ca}-\mathrm{Mg}$ type carbonates, reedmergnerite, and their accessory minerals. Based on the basic name of the rock, the relative content of alkaline minerals (Na-type carbonates, $\mathrm{Na}-\mathrm{Ca}-\mathrm{Mg}$ type carbonates, reedmergnerite, and their accessory minerals are more than $50 \%$ ) was applied to finely determine rock names, such as sodium carbonate-bearing dolomitic sandstone, sandy dolomite-containing reedmergnerite, and dolomitic tuff-containing shortite. Finally, the rock sedimentary structure was applied to the nomenclature of the Fengcheng Formation, such as a compact, massive structure; siliceous reedmergnerite-bearing dolomitic sandstone; horizontal grain-layered northupite-bearing sandy dolomite; and shalestructure dolomite (Fig. 4).

\section{Analysis of sedimentary environment}

We took the $\mathrm{Sr}, \mathrm{Sr} / \mathrm{Ba}, \mathrm{V} / \mathrm{Ni}, \mathrm{Th} / \mathrm{U}, \mathrm{V} /(\mathrm{V}+\mathrm{Ni}), \mathrm{U} / \mathrm{Mo}$, and $\mathrm{Sr} / \mathrm{CU}$ values as geochemical indicators to analyze the water medium conditions and paleoclimate in sedimentary environments of the Fengcheng Formation of the Mahu Sag in Fengnan area. The results showed that the ancient water medium in the sedimentary period is in the sedimentary environment of the continental lacustrine basin with high salinity and anoxic (Fig. 5).

(1) $\mathrm{The} \mathrm{Sr} / \mathrm{Ba}$ ratio, which is the degree of enrichment of trace elements, is closely related to the depositional environment. The $\mathrm{Sr} / \mathrm{Ba}$ ratio in trace element parameters is typically used as an indicator of marine or terrestrial environments. The chemical properties of strontium and barium are similar, and the $\mathrm{Sr} / \mathrm{Ba}$ value affects paleosalinity. The change in the $\mathrm{Sr} / \mathrm{Ba}$ value is sensitive and can be used as a paleosalinity indicator. The larger the ratio is, the higher is the paleosalinity (Fu et al. 2016). The $\mathrm{Sr} / \mathrm{Ba}$ ratio in freshwater sediments is typically less than 1 , whereas in saltwater sediments, it is greater than 1 (Qiu et al. 2015). The results showed that the $\mathrm{Sr} / \mathrm{Ba}$ ratio of the Fengcheng Formation of the Mahu Sag in Fengnan is 0.09-2.95, with an average value of 1.18 , and Fengcheng formation is a salty lacustrine basin sedimentary environment.

(2) In the $\mathrm{Th} / \mathrm{U}$ ratio, the $\mathrm{U}$ element is enriched in sediments in a strongly reducing environment. The Th is unaffected by the oxidation-reduction environment of the water. The $\mathrm{Th} / \mathrm{U}$ ratio is $0-2$, representing a lean oxygen environment, and it can reach 8 in an oxidizing environment (Wang et al. 2017; Smolarek et al. 2017). The results showed that the $\mathrm{Th} / \mathrm{U}$ ratio of the Fengcheng Formation of the Mahu Sag in Fengnan is

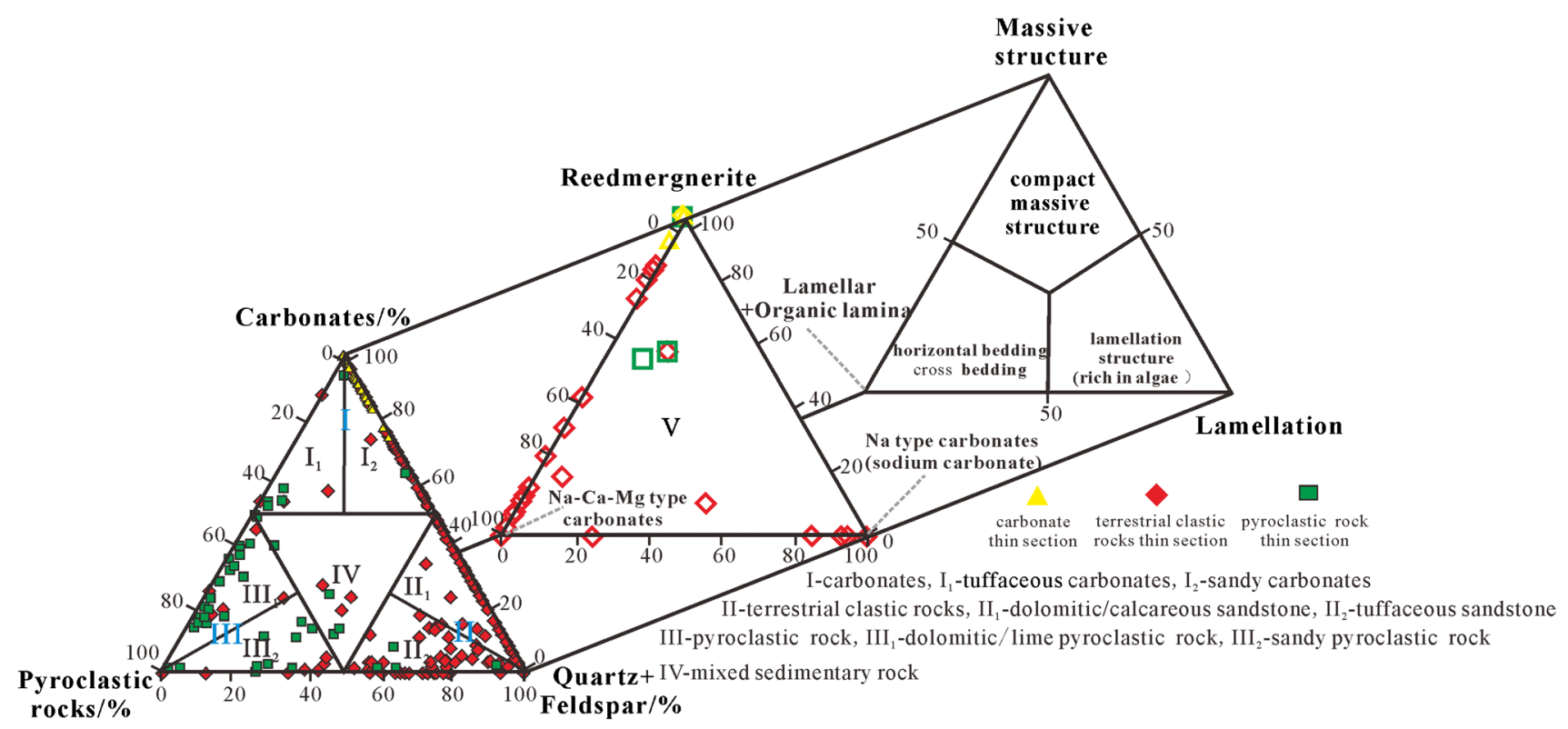

Fig. 4 Classification and nomenclature of lithofacies for the Fengcheng Formation in the Mahu Sag, Junggar Basin 


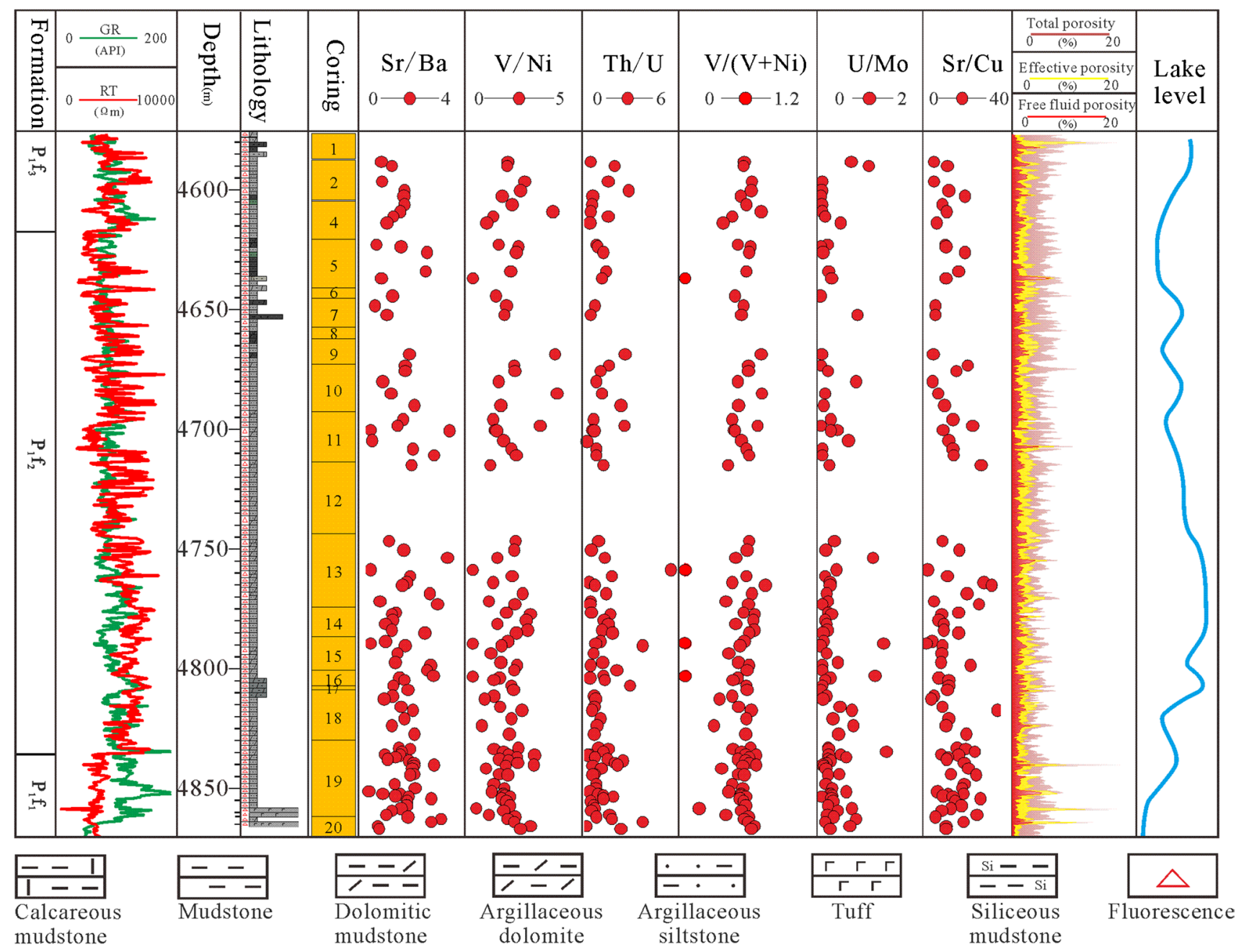

Fig. 5 Vertical variations of the trace elements for the Fengcheng Formation in the Mahu Sag, Junggar Basin

0.11-12.48, with an average value of 1.2 , indicating an anoxic deposition environment.

(3) In the $\mathrm{V} / \mathrm{Ni}-\mathrm{V} /(\mathrm{V}+\mathrm{Ni})$ ratio, $\mathrm{V}$ and $\mathrm{Ni}$ are elements of the iron group and are highly sensitive to the redox environment; they are also often used as a critical indicator for judging the salinity of deposition media (Makeen et al. 2019; Harris et al. 2004). V is easy to accumulate in an oxidizing environment and conditions with greater acidity, and $\mathrm{Ni}$ is easier to accumulate in a reducing environment and conditions with greater alkalinity. Typically, $\mathrm{V} / \mathrm{Ni}$ is used to analyze a sedimentary environment's paleosalinity. If the $\mathrm{V} / \mathrm{Ni}$ value is greater than 3 , it is a marine sedimentary environment, and if it is less than 3 , it is a continental sedimentary environment. $\mathrm{A} \mathrm{V} /(\mathrm{V}+\mathrm{Ni})>0.84$ is a quiet sea phasereducing environment, a $\mathrm{V} /(\mathrm{V}+\mathrm{Ni})$ ratio of $0.54-0.84$ indicates an anoxic environment, and a $\mathrm{V} /(\mathrm{V}+\mathrm{Ni})$ ratio of 0.46-0.58 indicates a lean oxygen-deposition environment. The results showed that the $\mathrm{V} / \mathrm{Ni}$ ratio of the
Fengcheng Formation in Fengnan is $0-5.33$, with an average value of 1.63 , indicating that the sedimentary water body is a continental-reducing sedimentary environment. The $\mathrm{V} /(\mathrm{V}+\mathrm{Ni})$ ratio of $0-0.84$, with an average value of 0.56 , indicates a lean oxygen-anaerobic deposition environment.

(4) Studies have confirmed that the $\mathrm{Sr} / \mathrm{Cu}$ ratio can effectively reflect changes in the paleoclimate of the lacustrine basin. A Sr/Cu ratio of 1.3-5 represents the temperature and humidity, and a $\mathrm{Sr} / \mathrm{Cu}$ ratio greater than 5 represents dry and hot conditions. The results showed that the $\mathrm{Sr} / \mathrm{Cu}$ ratio of the Fengcheng Formation of the Mahu Sag in Fengnan is 1.13-216.22 and the average value is 18.91 , indicating that it was formed in dry and hot conditions.

(5) The U/Mo ratio is a commonly used index to determine changes in the oxidation-reduction conditions of sedimentary water bodies (McManus et al. 2006; Lian et al. 2012). The results showed that the U/Mo ratio of 
the Fengcheng Formation of the Mahu Sag in Fengnan is $0.01-2.61$ and the average value is 0.36 . The overall value is too small, indicating an anoxic deposition environment (Table 1).

\section{Types of diageneses}

Diagenesis runs through the entire change process-from when sediments are buried and transformed into rocks to metamorphism or uplift to the surface before weathering occurs. During this process, due to changes in the buried depth, ground temperature, and overlying pressure, a series of changes will occur in the original sediments, directly affecting the rock pores' state and controlling the existence, formation, development, and evolution of pores. The main diagenesis types of the Lower Permian Fengcheng Formation in the Junggar Basin include compaction, pressolution, cementation, and metasomasis. Mechanical compaction is critical in the formation process of tight reservoirs, occurring in the early diagenetic stage, and it has an important impact on the reservoir's porosity and permeability and causes loss of intergranular pores. The compaction of the Fengcheng Formation in the Mahu Sag is strong. Clastic particles arrange directionally in the lamina, and carbonate particles are lined and concave-convex intergranular contacts.

With the increase in the burial depth, pressolution development increases in the dolomitic rock and pyroclastic reservoir of the Fengcheng Formation, and many parallel or low-angle stylolite structures can be observed. Sawtoothed stylolites are often filled with mudstone or asphalt (Fig. 6a-d). Dissolution improves the tight reservoir space. The Fengcheng Formation's dissolution mainly occurs in feldspar, rock debris, and carbonate particles, and the poreexpanded dissolution fissure can be seen locally. Feldspar dissolution in the reservoir is common, and the secondary dissolution pores are saturated with oil or filled with ankerite cement of the late diagenetic stage (Fig. 6e-h). TS observations, SEM, and XRD results showed three cement types in the Fengcheng Formation (carbonate, clay mineral, and a small amount of siliceous). Carbonate cement, with the characteristics of widely distributed, multiphased, and diverse genetic types, has a significantly destructive effect on pore formation and evolution. The carbonate cement content of the Fengcheng Formation ranges from 2 to $27 \%$, the calcite content ranges from 1 to $33 \%$, and the ankerite content ranges from 2 to $30 \%$, and carbonate cement has a crystal stock or poikilitic texture.

Three clay mineral cement types are observed in the Fengcheng Formation (chlorite, illite/smectite mixed layers, and illite). Curved flaky chlorite and honeycomb illite/smectite mixed layers are filled in primary residual intergranular and dissolution pores. Illite in is hair and silk shaped (Fig. 6i-1). Pervasive metasomatism occurs in the Fengcheng
Formation. Reedmergerite replaced dolomite, shortite, and calcite and carbonate mineral replaced tuffaceous, quartz, and feldspar. Ankerite has a cloudy center and a clean rim structure (Fig. 6m-p).

The terrestrial clastic grains are arranged in obvious directions due to mechanical compaction, and the dissolution pores in the albite and calcite grains are well developed. The carbonate particles are mainly linear and concave-convex in close contact. They are typically formed by late diagenetic metasomatism, such as dolomitization and recrystallization, to form intercrystalline pores in shale reservoirs. The pore sizes are typically less than a few microns. Pyroclastic rocks mainly comprise dissolution pores, and the phenomena of dedolomitization, local silicification, and chloritization are common. Pressure dissolution is widely developed in volcaniclastics reservoirs, and many parallel or low-angle stylolite structures intersect in rock layers can be seen. The secondary recrystallization of salt rocks and alkaline mineral dissolution is also strong, and the phenomenon of dissolution pores and caves can be seen. In the mixed rocks, the reedmergnerite replaced dolomite and carbonate minerals such as shortite and calcite replaced quartz and feldspar particles. Most dolomites in the Fengcheng Formation are metasomatic ankerite.

\section{Multiscale characterization of reservoir space types}

The Fengcheng Formation of the Mahu Sag in Fengnan has multiple reservoir space types, such as rock fractures, stylolites, and micro-nanoscale pore-throat systems. Based on the above analysis, research was conducted on the reservoir space types of the Fengcheng Formation shale oil in the Mahu Sag on logging, core, and micropore-throat scales.

The macroreservoir space types of the Fengcheng Formation include tectonic, induced, bedding, and dissolution-expansion fracture types.

(1) Tectonic fractures: under regional tectonic compression or shear strike-slip conditions, the Fengcheng Formation produced ruptures and deformation, forming highangle fractures, medium-low-angle fractures, fracture networks, and other complex tectonic fracture systems (Fig. 7a-c). High-angle fractures and fracture networks are mostly filled with calcite, quartz, carbon, and mud. Sheared fractures are relatively straight. The fracture aperture is large, mostly open or partially filled, with good connectivity, long-distance extension, and concentrated distribution in local places (Fig. 7e, f).

(2) Induced fractures in the Fengnan area are formed by the interaction of well-bore pressure and rock formations during the drilling process. The fractures are often distributed in the middle of the core. Drilling-induced 


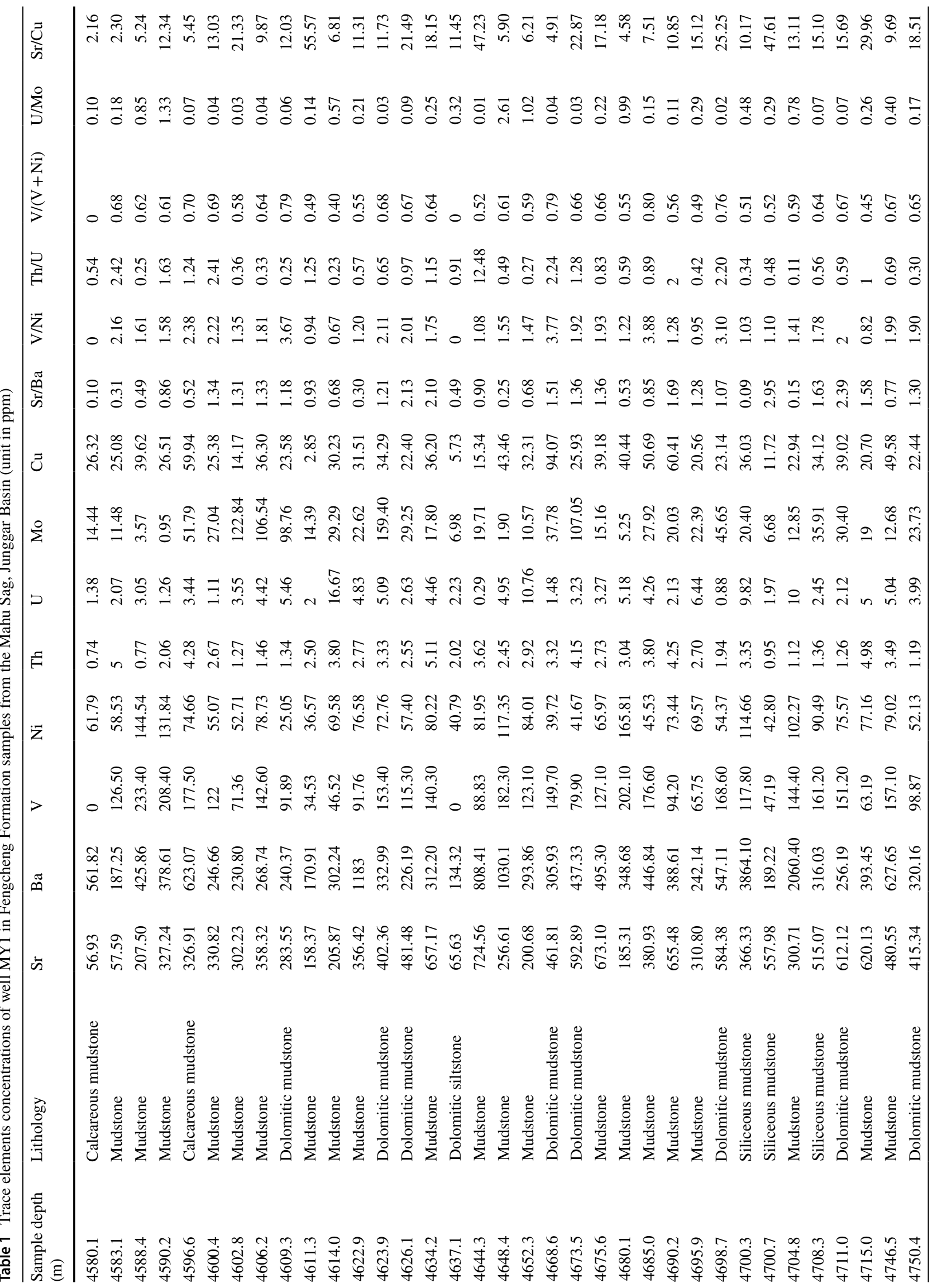




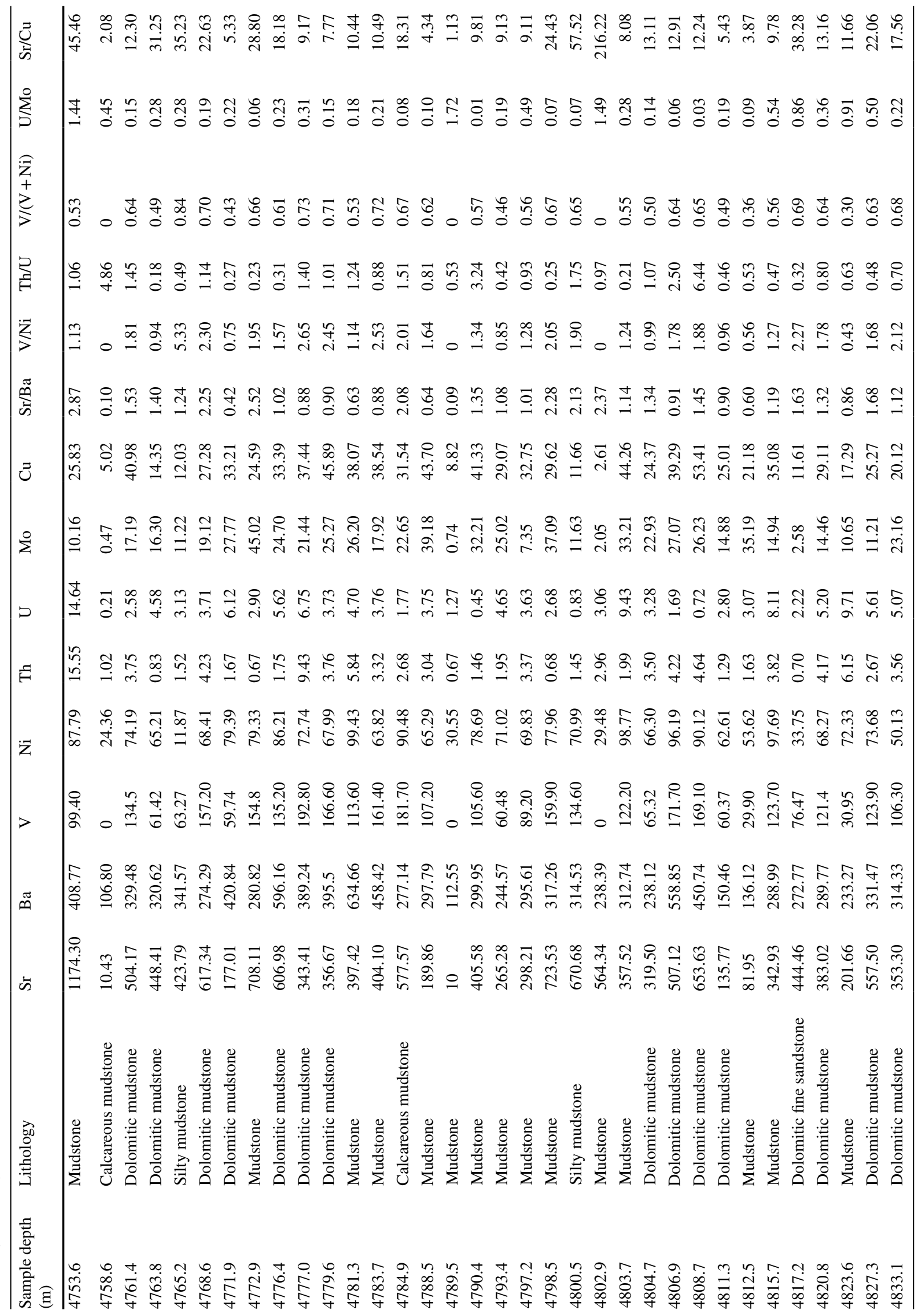



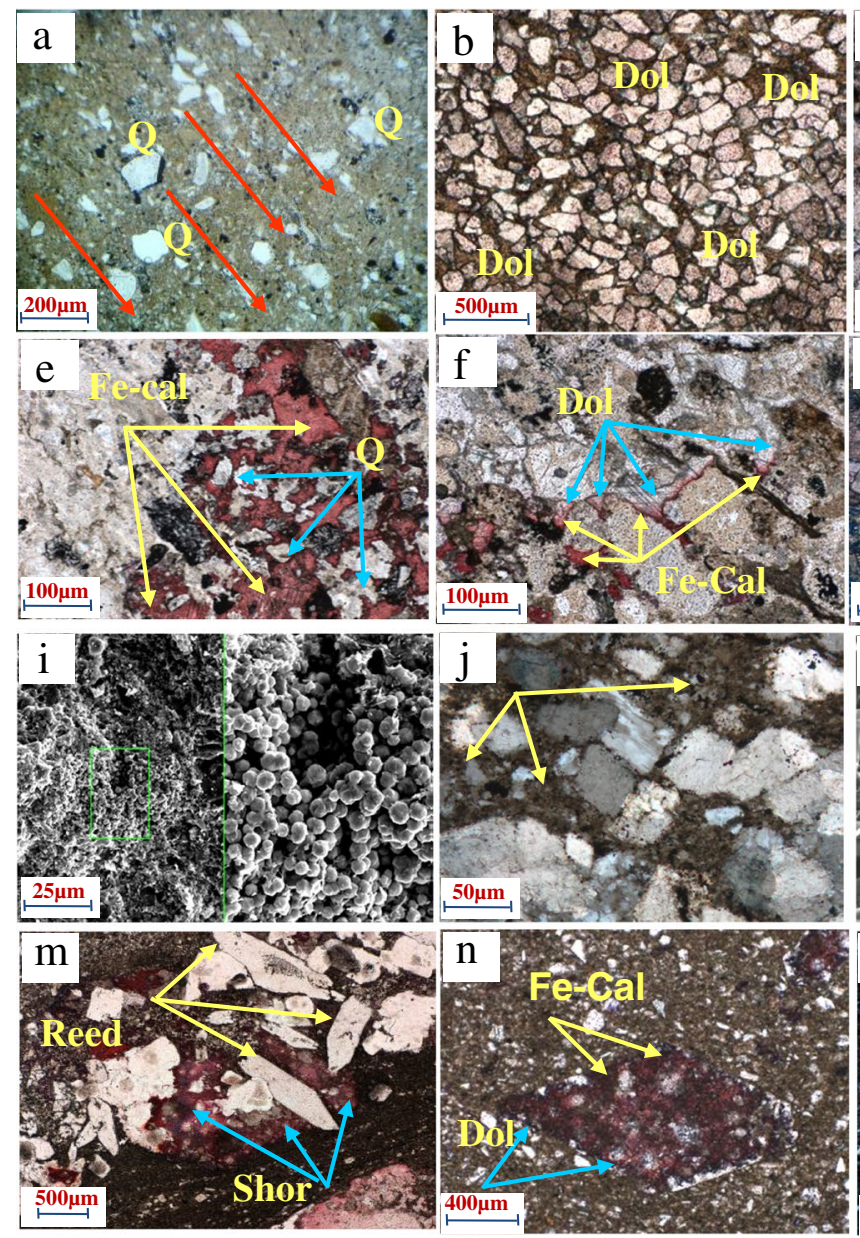

Fig. 6 Photographs showing the diagenesis types of the Fengcheng Formation in the Mahu Sag, Junggar Basin. a Mineral grains alined in one direction, from well MY1, $4613.94 \mathrm{~m}$, PPL. b Carbonate grains point-line contact, from well F5, 3197.13 m, PPL. c Mineral grains closely contact, from well FN3, 3959.47 m, PPL. d Stylolites structure, from well FN4, $4579.6 \mathrm{~m}$, PPL. e Crystal stock calcite cement (dyed red), from well FN3, 3959.47 m, PPL. f Calcite (dyed red) replacing dolomite, from well FN4, $4579.72 \mathrm{~m}$, PPL. g Ankerite cement (dyed blue), from well FN1, 4234.95 m, PPL. h Ankerite cement (dyed blue), from well F7, $3448.9 \mathrm{~m}$, PPL. i Pyrite aggregation, from well FC1, 4274.07 m, SEM. j Quartz, feldspar fragments,

fractures are symmetrically distributed on the formation microimage (FMI) as two black bands parallel to the well axis, have stable orientation, and are extended for a long distance.

(3) Dissolution-expansion fractures. Tectonic fractures developed in the early stages or zones of secondary dissolution pores have become critical drainage channels for geological dissolution fluids in the later stage and promoted dissolution fracture development. FMIs reveal pinhole-shaped pores formed by dissolution, and the dissolution pore distribution presents a layered structure. The thickness is typically several meters, and resistivity-logging curves commonly feature low val-
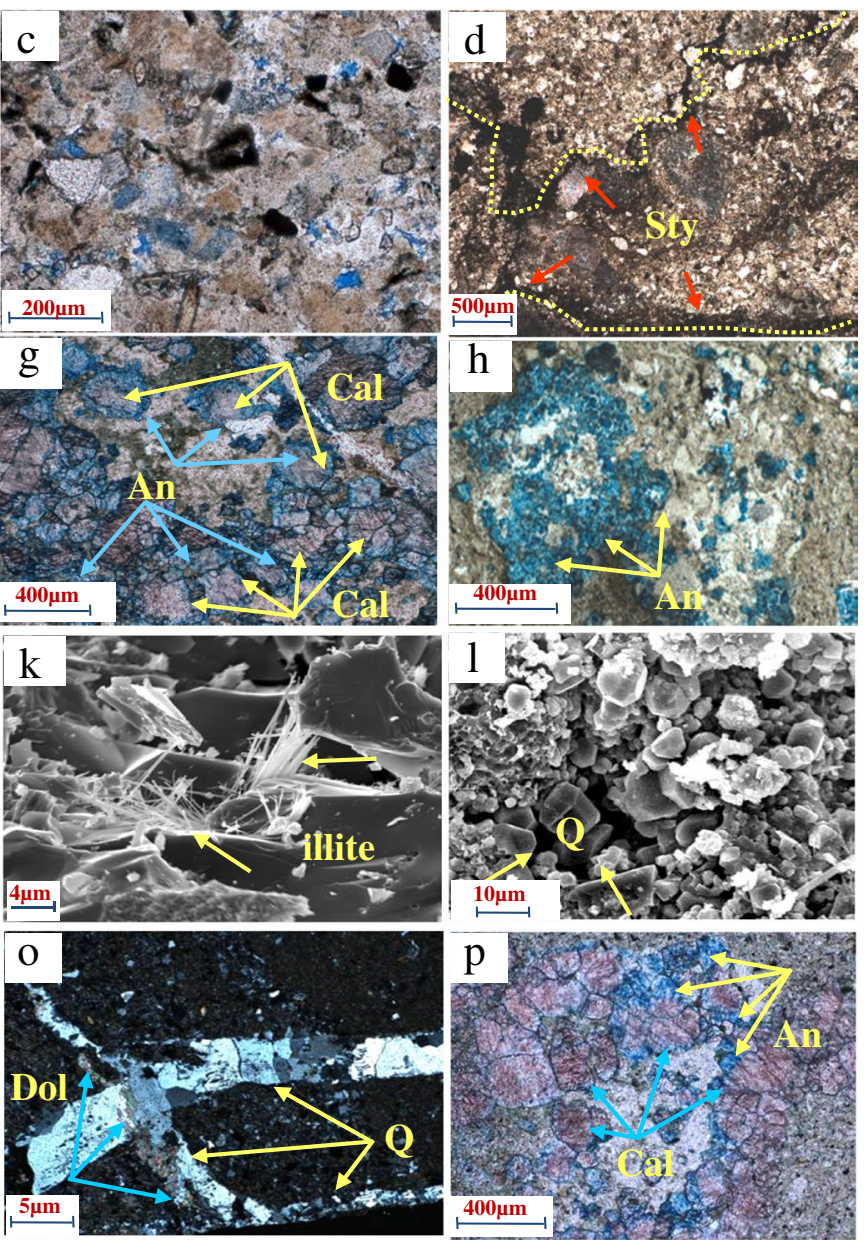

clay minerals cement filling the pores, from well MY1, $4697.53 \mathrm{~m}$, SEM. k Hair-shape/silk-shape illite cement filling the pores, from well AK1, 5664.15 m, SEM. I Quartz overgrowths, from well FN2, $4102.21 \mathrm{~m}$, SEM. m Reedmergnerite replacing shortite (dyed red), from well FN7, 4598.37 m, PPL. n Ferro-calcite replacing dolomite (dyed purple), from well W35, $3371.51 \mathrm{~m}$, PPL. o Dolomite replacing quartz veins, from well F5, $3480.3 \mathrm{~m}$, XPL. p Ankerite replacing calcite, from well FN1, $4090.31 \mathrm{~m}$, PPL. (PPL plane-polarized light, XPL cross polarized light, SEM scanning electron microscope, Q quartz, Dol dolomite, Sty styolite, Fe-Cal Ferro-calcite, Cal calcite, An ankerite, Reed reedmergnerite, Shor shorite)

ues (Fig. 7d). The tectonic dissolution fractures of the Fengcheng Formation are mostly developed in muddy and sandy dolomites, with fracture widths ranging from 1 to $12 \mathrm{~mm}$, either open or partially filled. The dissolution fractures' shape at the core scale is irregular, and the fracture surfaces are often uneven, with the appearance of dissolution pores and caves (Fig. 7g, j, and k).

(4) Bedding fractures. Compared with the macrotectonic fractures, the length and scale of bedding fractures in the Fengcheng Formation are smaller and mostly horizontal, increasing the pore network connectivity and promoting secondary pore development. It is also an 

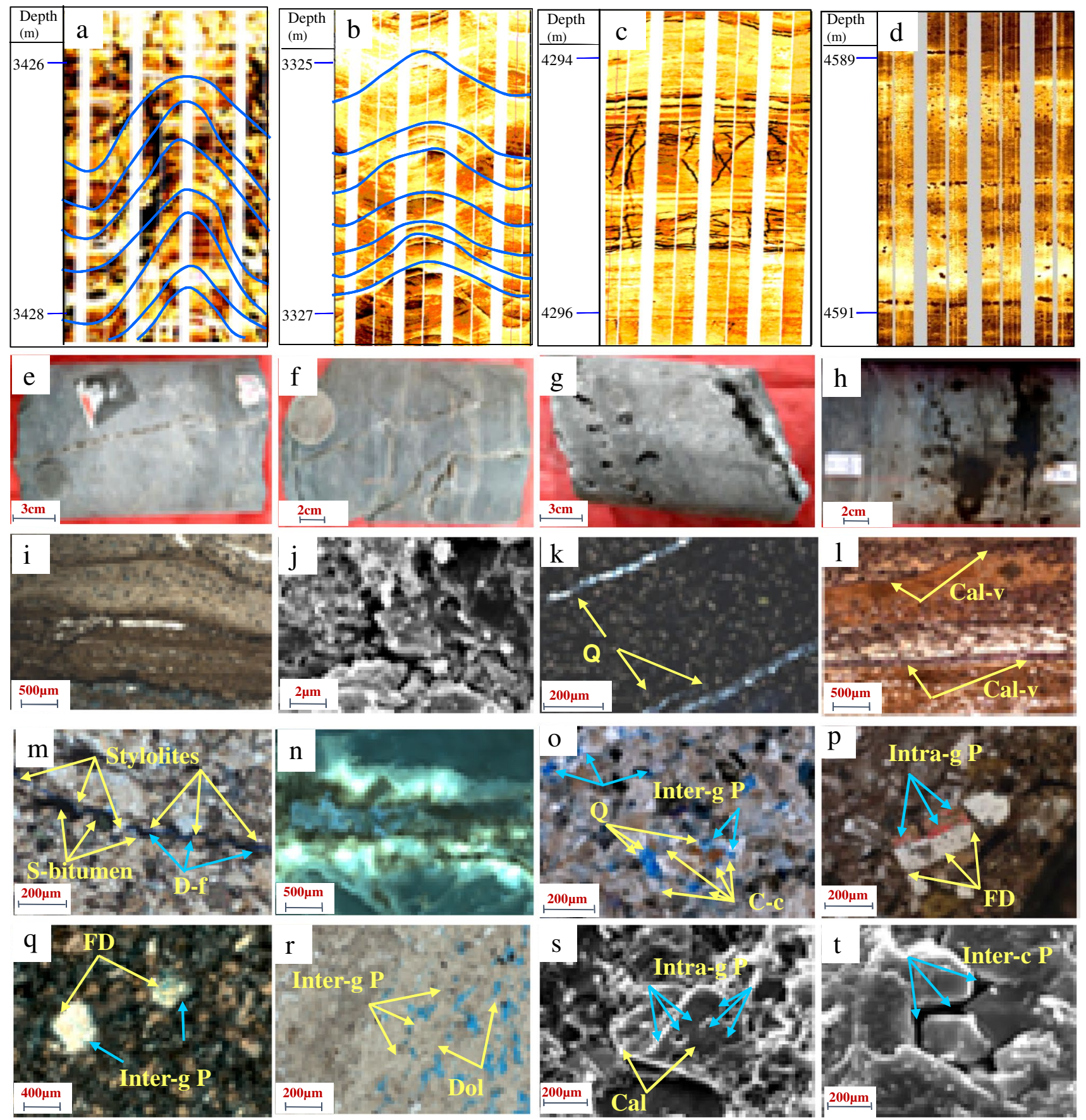

Fig. 7 Photographs showing the reservoir pace types on a multiscale in the Fengcheng Formation of the Mahu Sag, Junggar Basin. a Highangle fracture, from well Wu35, $3426.01 \mathrm{~m}$, FMI. b Middle-angle fracture, from well FN5, $3325.01 \mathrm{~m}$, FMI. c Net fracture, from well FN4, 4294.02 m, FMI. d Dissolved pore and bedding fracture, from well MY1, 4587.98 m, FMI. e Dolomitic mudstone with oil spot, micro tectonic fracture, from well FN1, 4183.10 m, CP. f Dolomitic mudstone, net fracture, from well F5, 3231.20 m, CP. g Argillaceous dolomite containing oil spot, dissolved fracture, from well FN3, $4128.20 \mathrm{~m}$, CP. h Dolomitic mudstone, bedding fracture, from well MY1, 4607.10 m, CP. i Dolomite rock, fracture crossing particle, from wellF8, $3167.91 \mathrm{~m}$, PPL. j Fracture along particle margin, from well Wu35, $3508.62 \mathrm{~m}$, SEM. k Structure fracture filled by quartz, from wellF26, $3295.97 \mathrm{~m}$, PPL. I Calcite vein fill the tectonic fracture, from well FN1, 4098.5 m, PPL. m Dissolution expansion fracture along stylolites, from well FN3, 3959.47 m, CTS. n Organic matter fill the stylolites, from well FN5, 4066.07 m, FTS. o Mineral grains closely contact, from well FN3, 3959.47 m, CTS. p Intra-granular dissolution pore in feldspar, from well Wu13, 3281.11 m, XPL. q Inter-granular dissolution pore in feldspar, from well MY1, $4589.97 \mathrm{~m}$, XPL. r Dissolution pore in dolomite, from well MY1, $4592.45 \mathrm{~m}$, PPL. s Intra-granular dissolution pore of calcite, SEM, from well FC011, $3340.01 \mathrm{~m}$, SEM. t Inter-crystalline pore, from well FN4, 4579.79 m, SEM (FMI fullbore formation micro-imager, CP core photo, PPL plane-polarized light, XPL cross polarized light, CTS casting thin section, FTS fluorescence thin section, SEM scanning electron microscope, Q quartz, Cal-v calcite vein, D-F dissolution fracture, C-c carbonate cement, Inter-g P inter-granular pore, Intra-g P intra-granular pore, FD feldspar, Dol dolomite, Cal calcite, Inter-c P inter-crystalline pore) 
Fig. 8 Burial depth, vitrinite reflectance, and diagenetic history of the Fengcheng Formation in the Mahu Sag, Junggar Basin. The width of the symbols represents the relative occurrence rate of the authigenic minerals and oil charging

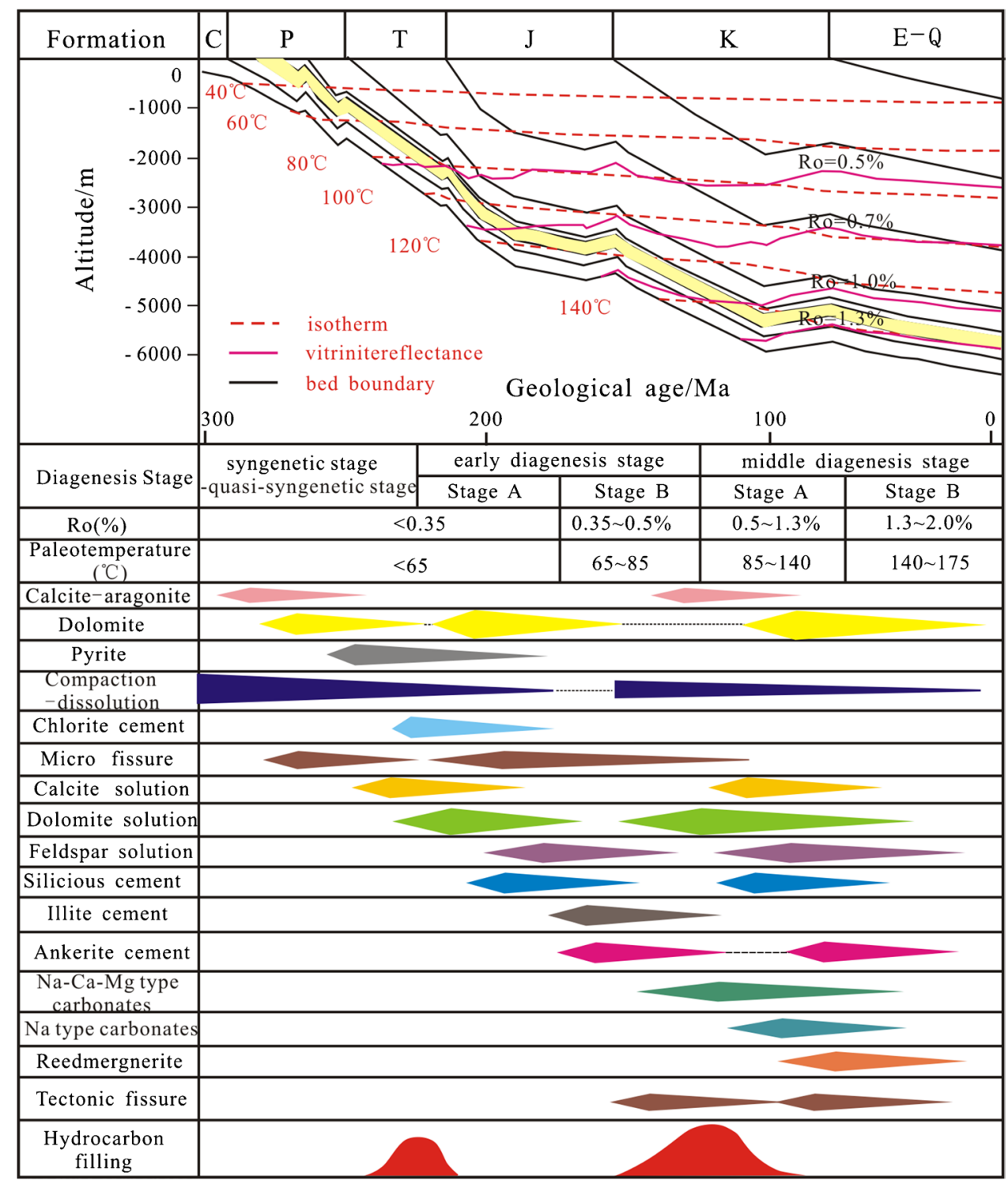

effective reservoir storage space, favorable for horizontal drainage and shale oil local accumulation (Fig. 7h).

The microreservoir space types of the Fengcheng Formation include microfractures and stylolites and micro-nanoscale pore throats.

(1) TS and SEM revealed that the Fengcheng Formation developed two types of microreservoir space types (transgranular microfractures and pressure-solution stylolites) (Fig. 7i, m, and n). The transgranular microfractures are tectonic, mostly developed in brittle rocks, such as dolomite and dolomitic siltstone. They often cut through multiple mineral particles, and the fracture width ranges from 20 to $80 \mu \mathrm{m}$, with a dendritic shape and a long-distance extension. Microscopically, pres- sure-dissolution fracture surfaces are mostly curved or irregular with a short extension distance. They mostly connect the dissolution and intercrystalline pores of mineral particles, forming a three-dimensional porefracture drainage system for shale oil. The stylolites in the Fengcheng Formation often experienced multistage dissolution or were filled with minerals such as dolomite and ankerite.

(2) The micro-nanoreservoir space of the Fengcheng reservoirs in the Mahu Sag mostly includes multiple pore types such as intergranular dissolved pores, intragranular dissolved pores, intercrystalline micropores, and a small amount of primary intergranular pores (Fig. 7o-t). Intergranular pores refer to pores between mineral grains. During diagenetic evolution, primary intergranular pores are formed by mutual support and 


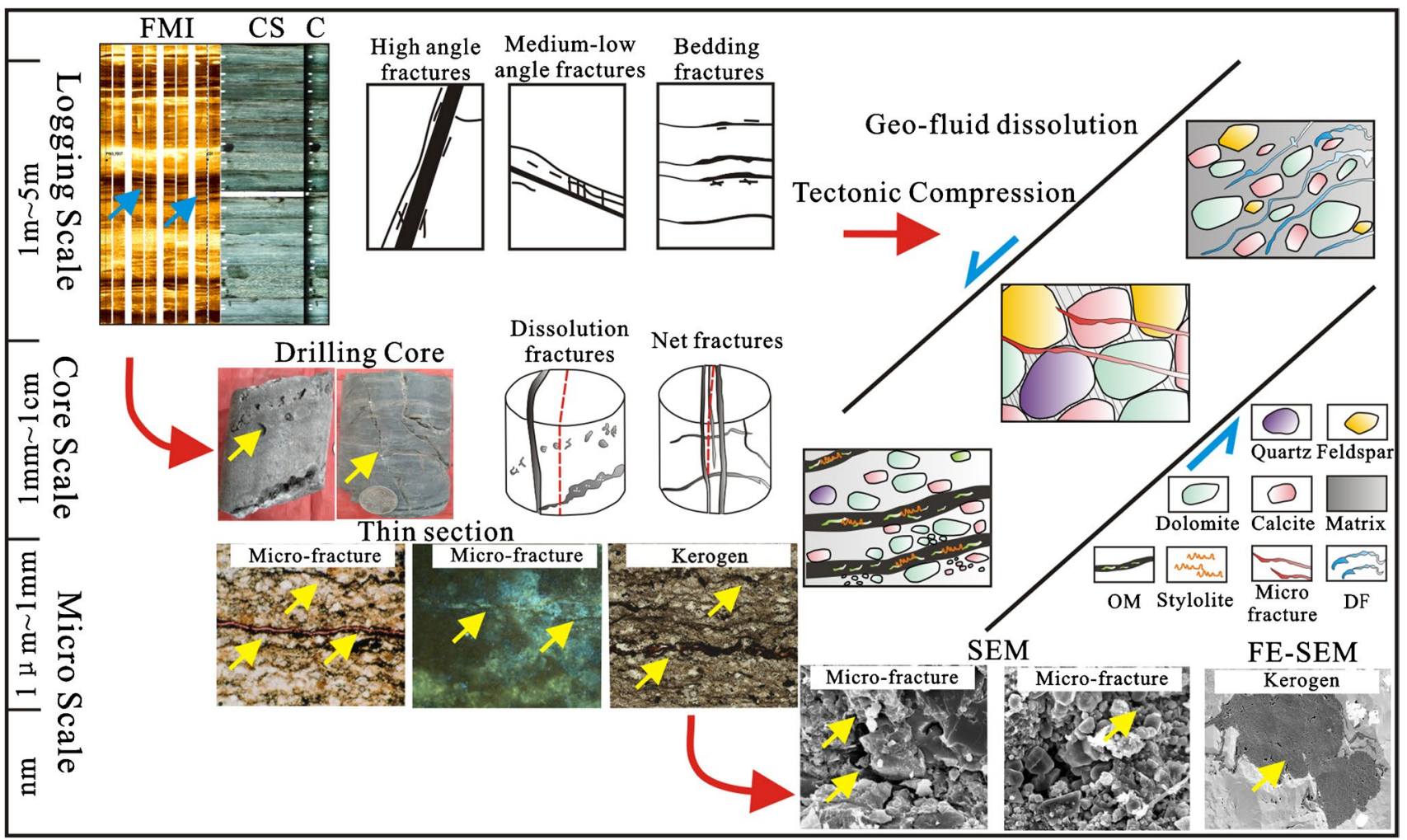

Fig. 9 Photographs showing multi-scale reservoir space in Fengcheng Formation of the Mahu Sag, Junggar Basin. FMI fullbore formation microimager, CS core scanning, C core, SEM scanning electron microscope, OM organic matter, DF dissolution fracture, FE-SEM field emission scanning electron microscope
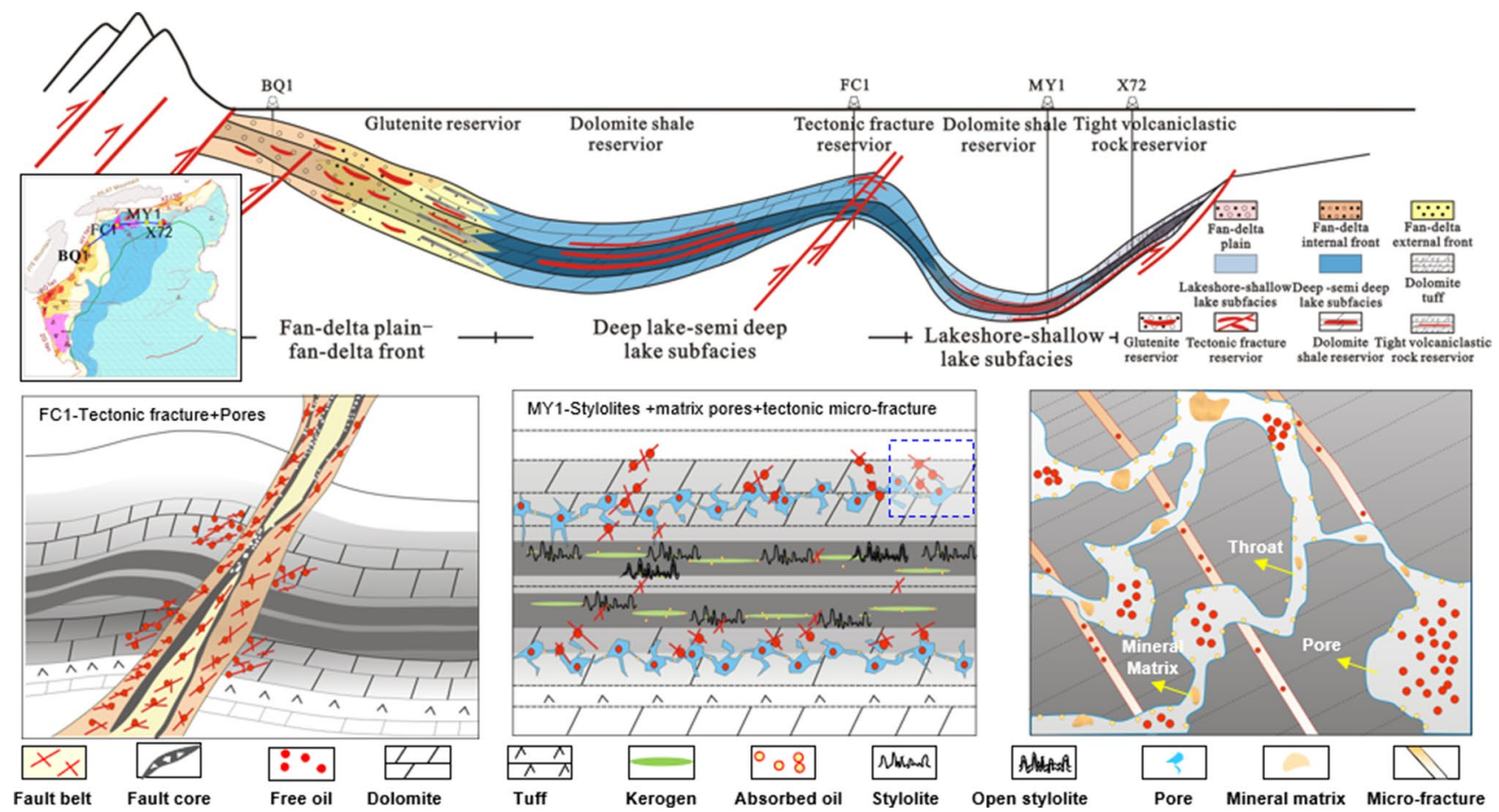

Fig. 10 Photographs showing reservoir space model of source-reservoir in Fengcheng Formation of the Mahu Sag, Junggar Basin 
overlap between brittle grains such as quartz and calcite, and between mineral grains and detritus. SEM showed that intergranular pores in the Fengcheng Formation shale oil reservoirs of the Mahu Sag, Junggar Basin, are mostly of the micrometer scale, ranging from a few micrometers to tens of micrometers. The pores are mainly among quartz, feldspar, and quartz and feldspar particles. The pore morphology is mostly elliptic, triangular or polygon, and elongated or irregular.

Secondary pores refer to the pores formed by the influence of diagenetic epigenesis after deposition. It includes intercrystalline pores, dissolved pores, and a few dissolved caves. Such pores are important storage spaces for Fengcheng reservoirs. Secondary dissolution pores are caused by selective mineral dissolution. The pores are formed by the complete or partial dissolution of various clastic particles and within diagenetic minerals, such as feldspar grains, calcite grains, dolomite grains, and intermediate pores (Fig. 7b-e). Intercrystalline pores in the Fengcheng Formation shale reservoirs are small, typically no more than a few micrometers, and are mostly formed by late diagenetic metasomatism, such as dolomitization and recrystallization. Intercrystalline pores are more common in authigenic minerals, such as the pores formed between crystalline minerals, such as calcite and dolomite (Fig. 7f). Intercrystalline pore distribution is uneven, with numerous but extremely small pore diameters. The pore-throat diameter is typically less than $1 \mu \mathrm{m}$, mostly $100-500 \mathrm{~nm}$. They often coexist with fracture zones and contribute to the formation of sweet spots in tight reservoirs.

\section{Discussion}

\section{Diagenesis evolution sequence}

Based on the reconstruction of burial and thermal history of the Fengcheng Formation in the Mahu Sag and analysis of the diagenetic environment, sequence, system, and stage, the reservoir is currently in the middle of diagenetic-stage B (Fig. 8). The diagenetic evolution sequence of the Fengcheng Formation is established as follows. Eogentic microcrystalline high-magnesium calcite and aragonite precipitation -penecontemporaneous dolomitization-pyritization -calcite cementation and metasomatism -compaction-chlorite precipitation-dissolution-silicification -illite cementation -ankerite cementation-Na-Ca-Mg-type carbonates (shortite, eitelite, and northupite)-alkaline minerals (sodium carbonate, sodium bicarbonate)-reedmergnerite and late fissure. The results showed that the diagenetic of the Fengcheng Formation is diverse and the diagenetic system is relatively complex. Compaction and dissolution; carbonate mineral cementation, such as calcite and ankerite in the middle diagenetic stage; and clay minerals, such as illite/smectite mixed layers, are the principal controlling factors for the reservoir's densification. Feldspar dissolution and carbonate particle cementation are critical for the diagenetic reformation of a tight reservoir.

\section{The reservoir space combination type of shale oil}

The shale oil-charging channel types identified by core observation, fluorescent TS, and FE-SEM include kerogen networks, tectonic fractures, stylolites, and micro-nanoscale pore-throat systems (Fig. 9). The organic kerogen network is a critical channel system for oil and gas charging and migration. If the hydrocarbon generated by the kerogen reaches a specific concentration, it can be migrated along the kerogen vein into the reservoir. The Fengcheng Formation's source rocks are rich in organic matter. Among them, kerogen types I-III are distributed in the $\mathrm{P}_{1} \mathrm{~F}_{3}$, and the main types in $\mathrm{P}_{1} \mathrm{~F}_{2}$ are $\mathrm{II}$ and $\mathrm{II}_{1}$, providing a favorable channel network for shale oil (Piane et al. 2018; Yang et al. 2020).

Tectonic fractures of the Permian in the Junggar Basin were mainly formed in the Hercynian and Indosinian tectonic movements. Affected by the heterogeneity of the rock formations, two sets of conjugate shear fractures occur in the NW-SE and NE-SW of the Mahu Sag (Zhang et al. 2019a, b, c). The NE-SW direction fault controls the fracture development. The extensively developed tectonic fractures in the Fengcheng Formation are critical to source-rock hydrocarbon expulsion. The tectonic fractures developed in dolomite or dolomitic mudstone are mostly high angled with a large cutting depth, and the joint surface is mostly filled with calcite or a carbonaceous pitch, appearing in groups with an obvious direction. Unfilled tectonic fractures are effective shale oil reservoir spaces, and shale oil extravasation along these tectonic fractures is significant. In the Fengcheng Formation without fractures, mineral matrix pores (intergranular, intragranular, and intercrystalline) dominate the reservoir space. The oil-bearing grade of such cored intervals is from the oil trace to the oil spot, and the fluorescence is light yellow and yellow. Therefore, the micro-nanoscale porethroat system is a vital channel type for shale oil charging.

The oil-bearing grade of terrestrial clastic rocks is oil immersion, with the developing micro-nanoscale pore-throat system. The oil-bearing grade of carbonates and pyroclastic rocks is the oil spot, with the developing micro-nanoscale pore-throat system and stylolite structure, and some are of the oil immersion grade. The oil-bearing grade of salt rocks is the oil spot, with the developing secondary dissolution pore in the microscale and intercrystalline pore in the nanoscale, and some are of the oil residue grade. The oil-bearing grade of mixed rocks is oil residues and spots, with the developing micro-nanoscale pore-throat system and stylolite structure. 
Shale oil charging is a complex geological process, and charging and micromigration rarely occur along a single channel. There are numerous stylolite structures in the source rocks of the Fengcheng Formation. The reservoir pore types are mainly secondary dissolution and intercrystalline pores, and the fractures are mainly tectonic (logging, core, and micropore-throat scales) and bedding. Channels with diverse types of geneses and scales interconnect to form a complex pore-fracture network system. This study shows that the Fengcheng Formation possesses two types of source-reservoir channel combination models: tectonic fracture-pore systems (tectonic fracture-type reservoirs) and stylolite-matrix pore-tectonic microfracture systems (shale oil reservoirs), forming the shale oil preponderant chargingchannel network. Hydrocarbons generated at an early stage were charged into the micro-nanoscale pore-throat system, changing the wettability of rock particles from water wet to oil wet, increasing the free oil content (Fig. 10).

\section{Conclusion}

The results showed that the Fengcheng sedimentary period of the Mahu Sag is in the dry and hot continental lacustrine basin, with a saltwater paleoenvironment and anoxic/ lean oxygen conditions. The Fengcheng Formation of the Mahu Sag is dominated by dark-colored and fine-grained sedimentary rocks, with various rock types such as terrigenous fan delta clastic, lacustrine fine-grained carbonate, pyroclastic, and salt rocks. A classification and nomenclature scheme of the alkaline lake-type shale reservoir in the Fengcheng Formation has been formed using three lithologic component endmembers, alkaline mineral content, and sedimentary structure. Currently, the Fengcheng reservoirs of the Mahu Sag are in the mesogenetic stage B. It has experienced four diagenesis processes, including compaction and pressure dissolution, cementation filling, multistage dissolution, and metasomatic diagenesis. Fractures and secondary porosities are the principal reservoir space types in the Fengcheng Formation. This study showed that the Fengcheng Formation has two source-reservoir space combination models: tectonic fracture-pore systems (tectonic fracture-type reservoirs) and stylolite-matrix poretectonic microfracture systems (shale oil reservoirs), forming the shale oil preponderant charging-channel network. This study provides theoretical support and a scientific basis for the next step of shale oil exploration and deployment and a decision-making analysis in the Junggar Basin.

Acknowledgements We would like to thank Xinjiang Oilfield Branch Company Ltd., PetroChina for the permission to publish this work.
Funding This research was supported by the National Science and technology project (project number: 2017ZX050001002), the PetroChina Science and technology Project (Project number: 2019E2602) and the Petro-China Science and technology (Project number: 2021DJ1801).

\section{Declarations}

Conflict of interest The authors declare no competing interests.

Open Access This article is licensed under a Creative Commons Attribution 4.0 International License, which permits use, sharing, adaptation, distribution and reproduction in any medium or format, as long as you give appropriate credit to the original author(s) and the source, provide a link to the Creative Commons licence, and indicate if changes were made. The images or other third party material in this article are included in the article's Creative Commons licence, unless indicated otherwise in a credit line to the material. If material is not included in the article's Creative Commons licence and your intended use is not permitted by statutory regulation or exceeds the permitted use, you will need to obtain permission directly from the copyright holder. To view a copy of this licence, visit http://creativecommons.org/licenses/by/4.0/.

\section{References}

Angster S, Sarg J (2013) Regional and local fractures of the Bakken Petroleum System, Williston Basin: integrating field studies and 3-D seismic analysis. 65, pp 101-111

Blaizot M (2017) Worldwide shale-oil reserves: towards a global approach based on the principles of Petroleum System and the Petroleum System Yield. Bull Soc Geol Fr 188:33

Bowker K (2007) Barnett Shale gas production, Fort Worth Basin: issues and discussion. AAPG Bull 91:523-533

Burnham A (2017) Porosity and permeability of Green River oil shale and their changes during retorting. Fuel 203:208-213

Burton D, Woolf K, Sullivan B (2014) Lacustrine depositional environments in the Green River Formation, Uinta Basin: expression in outcrop and wireline logs. AAPG Bull 98:1699-1715

Camp W, Egenhoff S, Schieber J, Slatt R (2016) A compositional classification for grain assemblages in fine-grained sediments and sedimentary rocks-discussion. J Sediment Res 86:1-5

Cao J, Lei DW, Li YW, Tang Y (2015) Ancient high-quality alkaline lacustrine source rocks discovered in the lower Permain Fengcheng Formation, Junggar Basin. Acta Petrplei Sinica 36:781-790 (in chinese with English abstract)

Cao H, Zou Y, Lei Y, Xi D, Wan X, Peng P (2017) Shale oil assessment for the Songliao Basin, Northeastern China, using oil generationsorption method. Energy Fuels 31:4826-4842

Cao J, Xia LW, Wang TT, Zhi DM, Tang Y, Li WW (2020) An alkaline lake in the Late Paleozoic Ice Age (LPIA): a review and new insights into paleoenvironment and hydrocarbon potential. Earth Sci Rev 202:103091

Chao L, Cao Y, Jiang Z, Wu J, Song G, Wang Y (2017) Shale oil potential of lacustrine black shale in the Eocene Dongying depression: implications for geochemistry and reservoir characteristics. AAPG Bull 101:1835-1858

Chen G, Lu S, Zhang J, Wang M, Li J, Xu C, Pervukhina M, Wang J (2017) Estimation of enriched shale oil resource potential in E2s4L of Damintun Sag in Bohai Bay Basin, China. Energy Fuels 31:1-39 
Clarkson C, Pedemen P (2011) Production analysis of western Canadian unconventional light oil plays. SPE 1-23

Cui J, Li S, Mao Z (2019) Oil-bearing heterogeneity and threshold of tight sandstone reservoirs: a case study on Triassic Chang7 member, Ordos Basin. Mar Pet Geol 104:180-189

Dowey P, Taylor K (2020) Diagenetic mineral development within the Upper Jurassic Haynesville-Bossier Shale, USA. Sedimentology 67:47-77

EIA (2013) Annual Energy Outlook 2013 with Projections to 2040 [R]. Washington D C:U.S. Energy Information Administration

Fairbanks M, Ruppel S, Rowe H (2016) High-resolution stratigraphy and facies architecture of the Upper Cretaceous (Cenomanian-Turonian) Eagle Ford Group, Central Texas. AAPG Bull 100:379-403

French K, Birdwell J, Whidden K (2019) Geochemistry of a thermally immature Eagle Ford Group drill core in central Texas. Org Geochem 131:19-33

Fu H, Wang X, Zhang L, Gao R, Li Z, Xu T, Zhu X, Xu W, Li Q (2015) Investigation of the factors that control the development of pore structure in lacustrine shale: a case study of block $\mathrm{X}$ in the Ordos basin, China. J Nat Gas Sci Eng 26:1422-1432

Fu X, Wang J, Chen W, Feng X, Wang D (2016) Elemental geochemistry of the early Jurassic black shales in the Qiangtang Basin, eastern Tethys: constraints for palaeo-environment conditions. Geol J 51:443-454

Gamero-Diaz H, Miller C, Lewis R, Contreras-Fuentes C (2013) Evaluating the impact of mineralogy on reservoir quality and completion quality of organic shale plays [C]. AAPG Rocky Mountain Section Meeting, Salt Lake City, Utah

Guo H, He R, Wang L, Peng P, Lei Y, Luo X, Wang X, Zhang L, Jiang C (2018) Pore characteristics of lacustrine shale within the oil window in the Upper Triassic Yanchang Formation, southeastern Ordos Basin, China. Mar Pet Geol 91:279-296

Han Y, Horsfield B, Mahlstedt N, Wirth R, Curry D, LaReau H (2019) Factors controlling source and reservoir characteristics in the Niobrara shale oil system, Denver Basin. AAPG Bull 103:2045-2072

Harris N, Freeman K, Pancost R, White T, Mitchell G (2004) The character and origin of lacustrine source rocks in the Lower Cretaceous synrift section, Congo Basin, west Africa. AAPG Bull 88:1163-1184

Hentz T, Ambrose W, Smith D (2014) Eaglebine play of the southwestern East Texas basin: stratigraphic and depositional framework of the Upper Cretaceous (Cenomanian-Turonian) Woodbine and Eagle Ford Groups. AAPG Bull 98:2551-2580

Hu T, Pang X, Yu S, Wang X, Pang H (2015) Hydrocarbon generation and expulsion characteristics of Lower Permian P1f source rocks in the Fengcheng area, northwest margin, Junggar Basin, NW China: implications for tight oil accumulation potential assessment. Geol J 1-21

Jarvie D (2012) Shale resource systems for oil and gas: part 2-shale-oil resource systems $[\mathrm{M}]$. Shale reservoirs-giant resources for the $21 \mathrm{st}$ century. AAPG, Tulsa

Jiang S, Chen L, Wu Y, Jiang ZL, Mckenna E (2017) Hybrid plays of Upper Triassic Chang7 lacustrine source rock interval of Yanchang Formation, Ordos Basin, China. J Petrol Sci Eng 159:182-196

Kuhn P, Primio R, Hill R, Lawrence J, Horsfield B (2012) Threedimensional modeling study of the low-permeability petroleum system of the Bakken Formation. AAPG Bull 96:1867-1897

Lai J, Wang GW, Ran Y, Zhou Z, Cui Y (2016) Impact of diagenesis on the reservoir quality of tight oil sandstones: the case of Upper Triassic Yanchang Formation Chang 7 oil layers in Ordos Basin, China. J Petrol Sci Eng 145:54-65

Lazar O, Bohacs K, Macquaker J (2015) Capturing key attributes of fine-grained sedimentary rocks in outcrops, cores, and thin sections: nomenclature and description guidelines. J Sediment Res 85:230-246

Li X, Jiang Z, Song Y, Zhai G, Bao S, Li Z, Tang X, Wang P, Li T, Wang $G$ (2018) Porosity evolution mechanisms of marine shales at over-maturity stage: insight from comparable analysis between Lower Cambrian and Lower Silurian inside and at the margin of the Sichuan Basin, South China. Interpretation 6:1-56

Li W, Cao J, Zhi D, Tang Y, He W, Wang T (2021) Control on shale oil accumulation in alkaline lacustrine settings: Late Paleozoic Fengcheng Formation, northwestern Junggar basin. Mar Pet Geol 129:1-17

Lian Z, Wignall P, Jie S, Feng Q, Xie S, Zhao L, Huang J (2012) U/ Mo ratios and $898 / 95 \mathrm{Mo}$ as local and global redox proxies during mass extinction event. Chem Geol 324-325:99-107

Lu X, Shi J, Zhang S, Zou N, Sun G, Zhang S (2015) The origin and formation model of Permian dolostones on the northwestern margin of Junggar Basin, China. J Asian Earth Sci 105:456-467

Luo Q, Gong L, Qu Y, Zhang K, Zhang G, Wang S (2018) The tight oil potential of the Lucaogou Formation from the southern Junggar Basin, China. Fuel 234:858-871

Makeen Y, AbdullahAyinla H, Shan X, Liang Y, Su S, Noor NM, Hasnan H, Asiwaju L (2019) Organic geochemical characteristics and depositional setting of Paleogene oil shale, mudstone and sandstone from onshore Penyu Basin, Chenor, Pahang, Malaysia. Int J Coal Geol 207:52-72

McManus J, William M, Silke S, Poulson R, Holm C (2006) Molybdenum and uranium geochemistry in continental margin sediments: Paleoproxy potential. Geochim Cosmochim Acta 70:4643-4662

Milliken K, Esch W, Reed R, Zhang T (2012) Grain assemblages and strong diagenetic overprinting in siliceous mudrocks, Barnett Shale (Mississippian), Fort Worth Basin, Texas. AAPG Bull 96:1553-1578

Nelson P (2011) Pore-throat sizes in sandstones, siltstones, and shales: Reply. AAPG Bull 95:1448-1453

Ojha S, Misra S, Sinha A, Dang S, Tinni A, Sondergeld C, Rai C (2018) Relative permeability and production-performance estimations for Bakken, Wolfcamp, Eagle Ford, and Woodford Shale Formations. SPE Reservoir Eval Eng 21:307-324

Petrash D, Gueneli N, Brocks J, Mendez-Dot J, Gonzalez-Arismendi G, Poulton S, Konhauser K (2016) Black shale deposition and early diagenetic dolomite cementation during Oceanic Anoxic Event 1: the mid-Cretaceous Maracaibo Platform, northwestern South America. Am J Sci 316:669-711

Piane C, Bourdet J, Josh M, Clennell M, Rickard M, Saunders M, Sherwood N, Li Z, Dewhurst D, Raven M (2018) Organic matter network in post-mature Marcellus Shale: Effects on petrophysical properties. AAPG Bull 102:2305-2332

Pollastro R, Roberts L, Cook T (2012) Geologic model for the assessment of technically recoverable oil in the Devonian-Mississippian Bakken Formation, Williston Basin. AAPG Spec Vol 97:205-257

Qiu X, Liu C, Wang F, Mao G (2015) Trace and rare earth element geochemistry of the Upper Triassic mudstones in the southern Ordos Basin, Central China. Geol J 50:399-413

Sarg J, Suriamin N, Tìnavsuu-Milkeviciene K, Humphrey J (2013) Lithofacies, stable isotopic composition, and stratigraphic evolution of microbial and associated carbonates, Green River Formation (Eocene), Piceance Basin, Colorado. AAPG Bull 97:1937-1966

Smolarek J, Trela W, Bond D, Marynowski L (2017) Lower Wenlock black shales in the northern Holy Cross Mountains, Poland: sedimentary and geochemical controls on the Ireviken Event in a deep marine setting. Geol Mag 154:247-264

Sun N, Zhong J, Hao B, Ge Y, Swennen R (2020) Sedimentological and diagenetic control on the reservoir quality of deep-lacustrine sedimentary gravity flow sand reservoirs of the Upper Triassic 
Yanchang Formation in Southern Ordos Basin, China. Mar Petrol Geol 112:104050

Tao K, Cao J, Wang Y, Ma W, Xiang B, Ren J, Zhou N (2016) Geochemistry and origin of natural gas in the petroliferous Mahu sag, northwestern Junggar Basin, NW China: carboniferous marine and Permian lacustrine gas systems. Org Geochem 100:62-79

Taylor K, Macquaker J (2014) Diagenetic alterations in a silt- and clay rich mudstone succession: an example from the Upper Cretaceous Mancos Shale of Utah, USA. Clay Miner 49:213-227

Wang Z, Fu X, Feng X, Song C, Wang D, Chen W, Zeng S (2017) Geochemical features of the black shales from the Wuyu Basin, southern Tibet: Implications for palaeoenvironment and palaeoclimate. Geol J 52:282-297

Wang X, He S, Guo X, Zhang B, Chen X (2018) The resource evaluation of Jurassic Shale in North Fuling Area, Eastern Sichuan Basin, China. Energy Fuels 32:1213-1222

Wang T, Cao J, Carroll A, Zhi D, Li Y (2020) Oldest preserved sodium carbonate evaporite: Late Paleozoic Fengcheng Formation, Junggar Basin, NW China. Geological Society of America Bulletin

Wei Y, Liu G, Xu L, Niu X, Li C (2019) Petrographic and geochemical characteristics of organic-rich shale and tuff of the Upper Triassic Yanchang Formation, Ordos Basin, China: implications for lacustrine fertilization by volcanic ash. Can J Earth Sci 56:47-59

Xiong F, Jiang Z, Huang H, Wen M, Moortgat J (2019) Mineralogy and gas content of Upper Paleozoic Shanxi and Benxi Shale Formations in the Ordos Basin. Energy Fuels 3:1061-1068

Yan J, Zhang S, Wang J, Hu Q, Wang M, Chao J (2018) Applying fractal theory to characterize the pore structure of lacustrine shale from the Zhanhua Depression in Bohai Bay Basin, Eastern China. Energy Fuels 32:7539-7556

Yang Y, Liu J, Yao J, Kou J, Sun H (2020) Adsorption behaviors of shale oil in kerogen slit by molecular simulation. Chem Eng J 387:124054

Yao S, Zhang K, Hu W (2009) Sedimentary organic facies of the triassic Yanchang Formation in the Ordos Basin. Oil Gas Geol 30:74-84

Ye M, Xie X, Xu C, Du X, Song Z, Du X (2018) Dicussion for Classification-designation system of mixed siliciclastic-carbonate sediments and the implication for their reservoir prediction-a case study of mixed sediments from Bohai sea area. Geol Rev 64:1118-1131 (in chinese with English abstract)
Yu K, Cao Y, Qiu L, Sun P, Jia X, Wan M (2018) Geochemical characteristics and origin of sodium carbonates in a closed alkaline basin: the Lower Permian Fengcheng Formation in the Mahu Sag, northwestern Junggar Basin, China. Palaeogeogr Palaeoclimatol Palaeoecol 511:506-531

Zhang M, Li Z (2018) The lithofacies and reservoir characteristics of the fine-grained sedimentary rocks of the Permian Lucaogou Formation at the northern foot of Bogda Mountains, Junggar Basin (NW China). J Petrol Sci Eng 170:21-39

Zhang Z, Yuan X, Wang M, Zhou C, Tang Y, Chen X, Lin M, Cheng D (2018) Alkaline-lacustrine deposition and paleoenvironmental evolution in Permian Fengcheng Formation at the Mahu sag, Junggar Basin, NW China. Pet Explor Dev 45:1036-1049

Zhang J, Liu G, Cao Z, Tao S, Felix M, Kong Y, Yi Z (2019a) Characteristics and formation mechanism of multi-source mixed sedimentary rocks in a saline lake, a case study of the Permian Lucaogou Formation in the Jimusaer Sag, northwest China. Mar Pet Geol 102:704-724

Zhang T, Li X, Yin Y, He M, Liu Q, Huang L, Shi J (2019b) The transport behaviors of oil in nanopores and nanoporous media of shale. AAPG Bull 91:523-533

Zhang G, Wang Z, Guo X, Sun Y, Sun L, Pan L (2019c) Characteristics of lacustrine dolomitic rock reservoir and accumulation of tight oil in the Permian Fengcheng Formation, the western slope of the Mahu Sag, Junggar Basin, NW China. J Asian Earth Sci 178:64-80

Zhu S, Qin Y, Liu X, Wei C, Zhu X, Zhang W (2016a) Origin of dolomitic rocks in the lower Permain Fengcheng formation, junggar Basin, China: evidence from petrology and geochemistry. Miner Petrol 111(2):1-16

Zhu S, Zhu X, Liu X, Wu D, Zhao D (2016b) Authigenic minerals and diagenetic evolution in altered volcanic materials and their impacts on hydrocarbon reservoirs: evidence from the lower Permian in the northwestern margin of Junggar Basin, China. Miner Petrol 111(2):1-16

Zou C, Pan S, Horsfield B, Yang Z, Hao S, Liu E, Zhang L (2019a) Oil retention and intrasource migration in the organic-rich lacustrine Chang 7 shale of the Upper Triassic Yanchang Formation, Ordos Basin, central China. AAPG Bull 103:2627-2663

Zou C, Zhu R, Chen Z, Ogg J, Wu S, Dong D, Qin Z, Wang Y, Wang L, Lin S, Cui J, Su L, Yang Z (2019b) Organic-matter-rich shales of China. Earth Sci Rev 189:51-78 